\title{
Role of Metal Identity and Speciation in the Low-Temperature Oxidation of Methane over Tri-Metal Oxo Clusters
}

\author{
Jacklyn Hall ${ }^{1}$ and Praveen Bollini ${ }^{1}$ \\ ${ }^{1}$ University of Houston
}

May 6, 2021

\begin{abstract}
Clarity as to the role of metal identity and oxidation state in effecting redox and acid-catalyzed turnovers is oftentimes precluded by a high degree of heterogeneity in site speciation, a limitation that can be overcome through the use of well-defined polymetal clusters hosted by metal organic framework materials- accomplished in the present case using MIL-100(M) for the low temperature oxidation of methane with $\mathrm{N} 2 \mathrm{O}$. Transient kinetic data point to a) methoxy species mediating methane conversion, b) partial and deep oxidation occurring over metal sites distinct in oxidation state, c) chromium clusters amplifying the propensity toward $\mathrm{C}-\mathrm{C}$ bond formation, and d) the relative velocity of propagation of water and methanol concentration fronts playing a determinative role in maximizing $\mathrm{C} 2$ oxygenate selectivity. The study captures the utility of using classes of materials inherently endowed with a high level of definition and uniformity in advancing the elucidation of structure-catalytic property relationships.
\end{abstract}

\section{Introduction}

The selective, low-temperature oxidation of methane to methanol, if successfully accomplished, could enable valorization of vast reserves of shale gas resources becoming increasingly abundant in the United States and around the world. ${ }^{1-3}$ High-valent metal-oxo complexes serve as promising active centers for low-temperature methane oxidation, and are exploited in a variety of biological and synthetic systems; ${ }^{4-8}$ for instance, iron(IV)-oxo centers have been long hypothesized as the key oxidizing species in non-heme biological complexes including $\mathrm{R} 2$ proteins of ribonucleotide reductase (RNR R2), $\mathrm{Fe}^{2+} / \alpha$-ketoglutarate $(\alpha \mathrm{KG})$-dependent hydroxylates, and soluble methane monooxygenase (sMMO) enzymes. ${ }^{9-14}$ Efforts aimed at investigating such active centers have for the most part been focused on iron-zeolites in the heterogeneous catalysis literature ${ }^{15-19}$ and homogenous complexes in the bioinorganic chemistry literature ${ }^{20-23}$ with both classes of materials exhibiting unique limitations with respect to low temperature methane oxidation. Homogeneous complexes, on one hand, often display a propensity towards polynuclear aggregation, thereby limiting somewhat their use in catalysis applications. ${ }^{24-28}$ Iron-based zeolites, on the other hand, while ideal for investigating iron clusters that do not evolve significantly under reaction conditions, exhibit active site heterogeneity not only greater in degree than that exhibited by homogeneous complexes, but also to an extent that varies significantly with synthesis protocol, thermal treatment, and iron loading. ${ }^{29-31}$

Metal-organic framework materials (MOFs) potentially offer a solution to the challenge of synthesizing and evaluating materials that carry well-defined, structurally uniform metal-oxo moieties that remain isolated in nature subsequent to their involvement in catalytic redox cycles, with several copper and iron-containing MOFs having been evaluated for the oxidation of light alkanes including methane, ${ }^{32-35}$ ethane, ${ }^{36-38}$ and propane. ${ }^{39}$ Specifically, MIL-100 (MIL = Materials of Institut Lavoisier ) is a MOF that exhibits interesting properties in the partial oxidation of light alkanes. ${ }^{35,39-41}$ First discovered by Gérard Férey and coworkers, MIL-100 is comprised of trimetallic clusters $\left[\left(\mathrm{M}(\mathrm{III})_{3}\left(\mu_{3}-\mathrm{O}\right)\right]\right.$ coordinated by trimesate linkers to form a porous structure featuring an MTN (Mobile Thirty Nine) topology (Scheme 1a). ${ }^{42}$ Removal of terminal 
ligands $\left(\mathrm{H}_{2} \mathrm{O}\right.$ or $\left.\mathrm{X}^{-}\right)$through thermal activation under inert or vacuum at temperatures below $523 \mathrm{~K}$ (Scheme $1 b)$ creates unsaturated open-metal sites over mixed valence nodes $\left[\left(\mathrm{M}(\mathrm{II}) \mathrm{M}(\mathrm{III})_{2}\left(\mu_{3}-\mathrm{O}\right)\right] .{ }^{43-45}\right.$ The propensity of these nodes to convert methane to methanol at low temperatures (423

Scheme 1. (a) Structure of MIL-100 comprised of trimesic acid linkers and $\mu_{3}$-oxo centered trimer nodes. (b) Formation of $\mathrm{M}^{2+}$ and $\mathrm{M}^{3+}$ open-metal sites in MIL-100 through thermal activation resulting in the elimination of anionic ligands and coordinated water molecules, respectively.
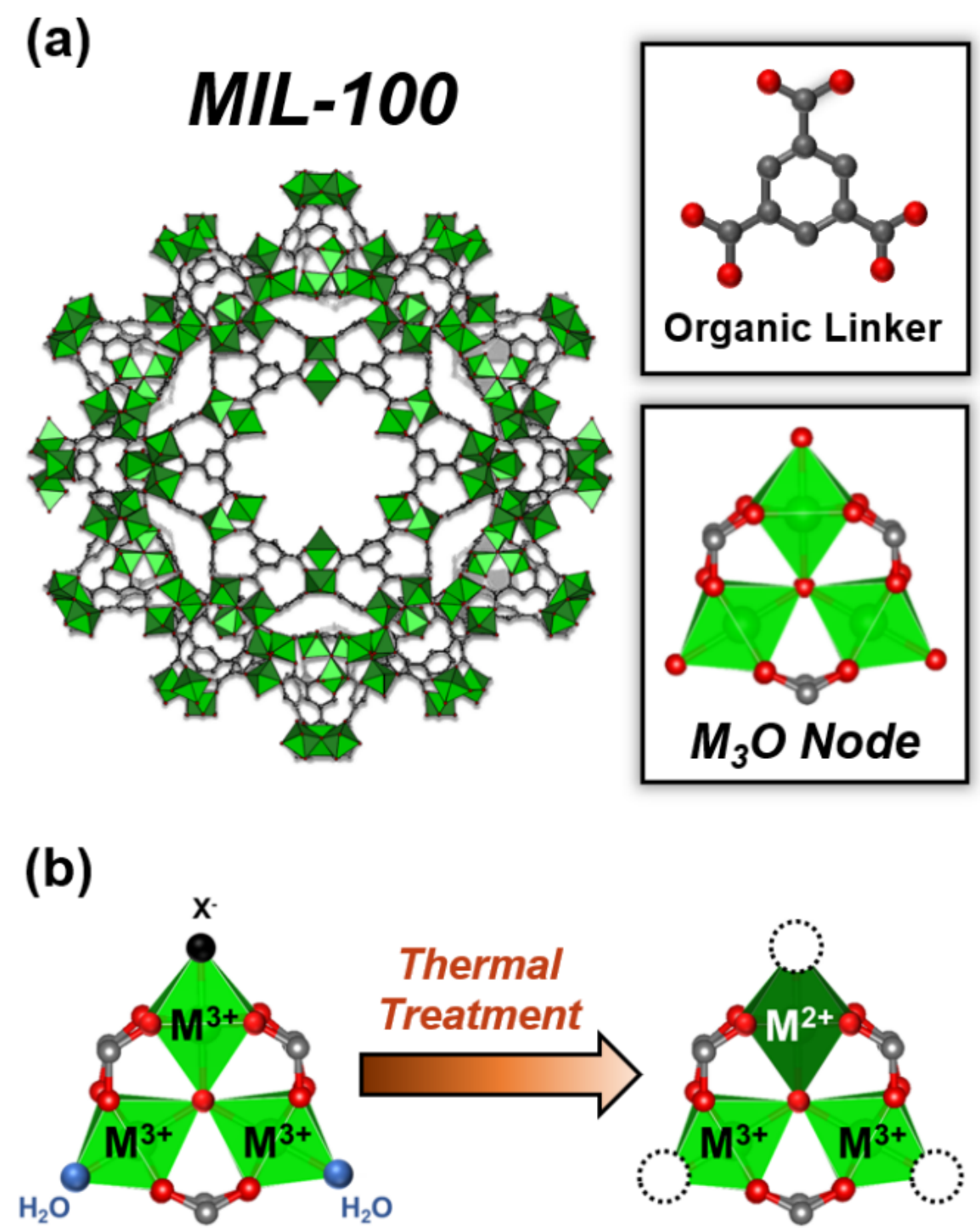

- $473 \mathrm{~K}$ ) and ambient pressures has been previously demonstrated, ${ }^{39,40}$ including a prior report from our group evidencing participation of every single MIL-100 tri-iron node towards methanol formation, ${ }^{35}$ unlike iron-zeolites that typically carry distributions of active and inactive multinuclear iron centers. ${ }^{46-49}$ In this study, we use a suite of spectroscopic, transient kinetic, and site titration tools to relate metal oxidation state to reactive function. Specifically, the role of $\mathrm{Fe}^{2+}$ and $\mathrm{Fe}^{3+}$ sites in methanol and $\mathrm{CO}_{2}$ formation are identified. Altering the identity of the metal from iron to chromium enables C-C bond formation events that appear to involve methoxy intermediates that also mediate methanol formation over both MIL-100(M) variants. To this end, we elucidate in Section 3.1 the identity of sites involved in $\mathrm{CO}_{2}$ and methanol formation, 
identify in Section 3.2 the role of methoxy intermediates, demonstrate the propensity towards and methods for controlling the prevalence of C-C bond formation over MIL-100(Cr) in Section 3.3, before clarifying the diversity of functionality of $\mathrm{Fe}^{3+}$-methoxies in Section 3.4 The study captures how precise control over metal identity and oxidation state, combined with manipulation of the relative velocity of water and methanol concentration fronts, enables control not only over the selectivity towards desired partial oxidation products such as methanol (versus $\mathrm{CO}_{2}$ ) but also that towards $\mathrm{C} 2$ oxygenates (over $\mathrm{C} 1$ oxygenates).

\section{Materials and Methods}

\subsection{Synthesis and characterization}

MIL-100(Fe) and MIL-100(Cr) were synthesized according to previously reported protocols ${ }^{50,51}$ that are described in detail in Sections S1.1 and S1.2. of the SI. Comparison of X-ray diffraction patterns, nitrogen physisorption isotherms, and thermogravimetric analysis profiles confirm the crystal structure, porosity, and composition, respectively, of these materials as being consistent with previous reports (Figure S1 and S2) ${ }^{50,51}$ Infrared (IR) spectroscopy measurements were conducted to track the evolution of $\mathrm{H}_{2} \mathrm{O}$ and $\mathrm{OH}^{-}$ coordinated species in MIL-100(Fe) and MIL-100(Cr) to estimate $\mathrm{M}^{2+} / \mathrm{M}^{3+}$ open-metal site densities under various thermal activation conditions (as described in detail in Section S1.6 of the SI). $\mathrm{Fe}^{2+}$ and $\mathrm{Fe}^{3+}$ openmetal site densities were quantified in-situ using a combination of breakthrough measurements with NO (0.5 $\mathrm{kPa}, 423 \mathrm{~K})$ and $\mathrm{D}_{2} \mathrm{O}(0.9 \mathrm{kPa}, 373 \mathrm{~K})$, as described in Sections 2.4 and 2.5 of the SI, respectively.

\subsection{Methane oxidation experiments}

Details of methane oxidation reaction experiments are described in Section S1.4 of the SI. Briefly, pretreated MIL-100 samples $\left(423-523 \mathrm{~K}, 12 \mathrm{~h}\right.$, He flow $\left(50 \mathrm{~mL} \mathrm{~min}^{-1}\right)$ or vacuum $\left(\mathrm{P}<1 \times 10^{-4}\right.$ bar $)$ ) were exposed to $\mathrm{CH}_{4} / \mathrm{N}_{2} \mathrm{O}$ reactant mixtures at $423-473 \mathrm{~K}$ with gas-phase product and reactant concentrations determined using a gas chromatograph (Agilent $7890 \mathrm{~B}$ ). Following reaction, water vapor at various partial pressures $(0.35-1.1 \mathrm{kPa})$ and molar flow rates $\left(1.54-4.61 \times 10^{-6} \mathrm{~mol} \mathrm{~s}^{-1}\right)$ were introduced to extract surface-bound intermediates at temperatures between 373 and $473 \mathrm{~K}$, and products formed were measured using an online mass spectrometer (MKS Cirrus 2).

\subsection{In-situ titrations}

Titration experiments with NO (10 wt.\% NO, balance $\mathrm{N}_{2}$, Matheson, Research Purity) and $\mathrm{H}_{2} \mathrm{O}$ (deionized, $18.3 \mathrm{M} \Omega$ ) were conducted at $423 \mathrm{~K}$ under constant reaction conditions: $14.5 \mathrm{kPa} \mathrm{N} \mathrm{N}_{2} \mathrm{O}, 1.5 \mathrm{kPa} \mathrm{CH}_{4}, \mathrm{t}=2$ h. For NO titration experiments, $\mathrm{NO}$ was fed over MIL-100(Fe) prior to the introduction of $\mathrm{CH}_{4}$ and $\mathrm{N}_{2} \mathrm{O}$ due to the significant time it takes for NO to break through the MOF bed in comparison to the reactants (Section S2.6, SI). Under titrant co-feeds, inert carrier gas (He, Matheson, Ultra High Purity) concentrations were reduced to maintain constant reactant partial pressures. Total quantities of $\mathrm{NO}$ and $\mathrm{H}_{2} \mathrm{O}$ adsorbed by MIL-100 were estimated through breakthrough curves measured using an online mass spectrometer (MKS Cirrus 2) at the outlet of the bed. Molar flow rates were calibrated with respect to those of argon (internal standard) under the assumption that no argon was adsorbed by the sample.

\section{Results and Discussion}

\subsection{Active site requirements for methanol and $\mathrm{CO}_{2}$ formation}

We previously reported the oxidation of methane to methanol and $\mathrm{CO}_{2}$ at low temperatures $(423-483 \mathrm{~K})$ and sub-ambient pressures over tri-iron oxo clusters hosted by MIL-100(Fe) nodes. ${ }^{35}$ Co-feeding $\mathrm{N}_{2} \mathrm{O}$ and methane at $473 \mathrm{~K}$ over MIL-100(Fe) activated at $523 \mathrm{~K}$ resulted in transient dinitrogen formation rates that decrease asymptotically toward a constant value and $\mathrm{CO}_{2}$ formation

rates that appear to be invariant in time (Figure 1). Extraction with water vapor $(0.35 \mathrm{kPa}, 473 \mathrm{~K})$ subsequent to exposure to methane and $\mathrm{N}_{2} \mathrm{O}$ resulted in the formation of methanol, the cumulative yield of which asymptotically approaches a maximum value with reaction time (Figure 1 ). Reported $\mathrm{N}_{2}$ formation rates are consistent with those expected based on the combination of methane oxidation to methanol, $\mathrm{CO}_{2}$ and water based on the reaction stoichiometry $\left(\mathrm{N}_{2} \mathrm{O}+\mathrm{CH}_{4}-\mathrm{N}_{2}+\mathrm{CH}_{3} \mathrm{OH} ; 4 \mathrm{~N}_{2} \mathrm{O}+\mathrm{CH}_{4}-4 \mathrm{~N}_{2}+\mathrm{CO}_{2}\right.$ 
$+2 \mathrm{H}_{2} \mathrm{O}$ ), as reflected by the close correspondence between measured cumulative nitrogen yields and those estimated from reaction stoichiometry (Figure 1). The maximum cumulative methanol yield measured corresponds to the theoretical maximum density of $\mathrm{Fe}^{2+}$ sites in MIL-100 (0.33 mol Fe${ }^{2+} / \mathrm{mol}$ total $\left.\mathrm{Fe}\right)$. Furthermore, $\mathrm{Fe}^{2+}$ site densities estimated from FTIR signatures of either terminal hydroxyl ligands or NO coordinated to $\mathrm{Fe}^{2+}$ sites created upon hydroxyl removal serve as proxies for cumulative methanol formation, lending credence to the possible sole involvement of $\mathrm{Fe}^{2+}$ sites in methanol formation. ${ }^{35}$

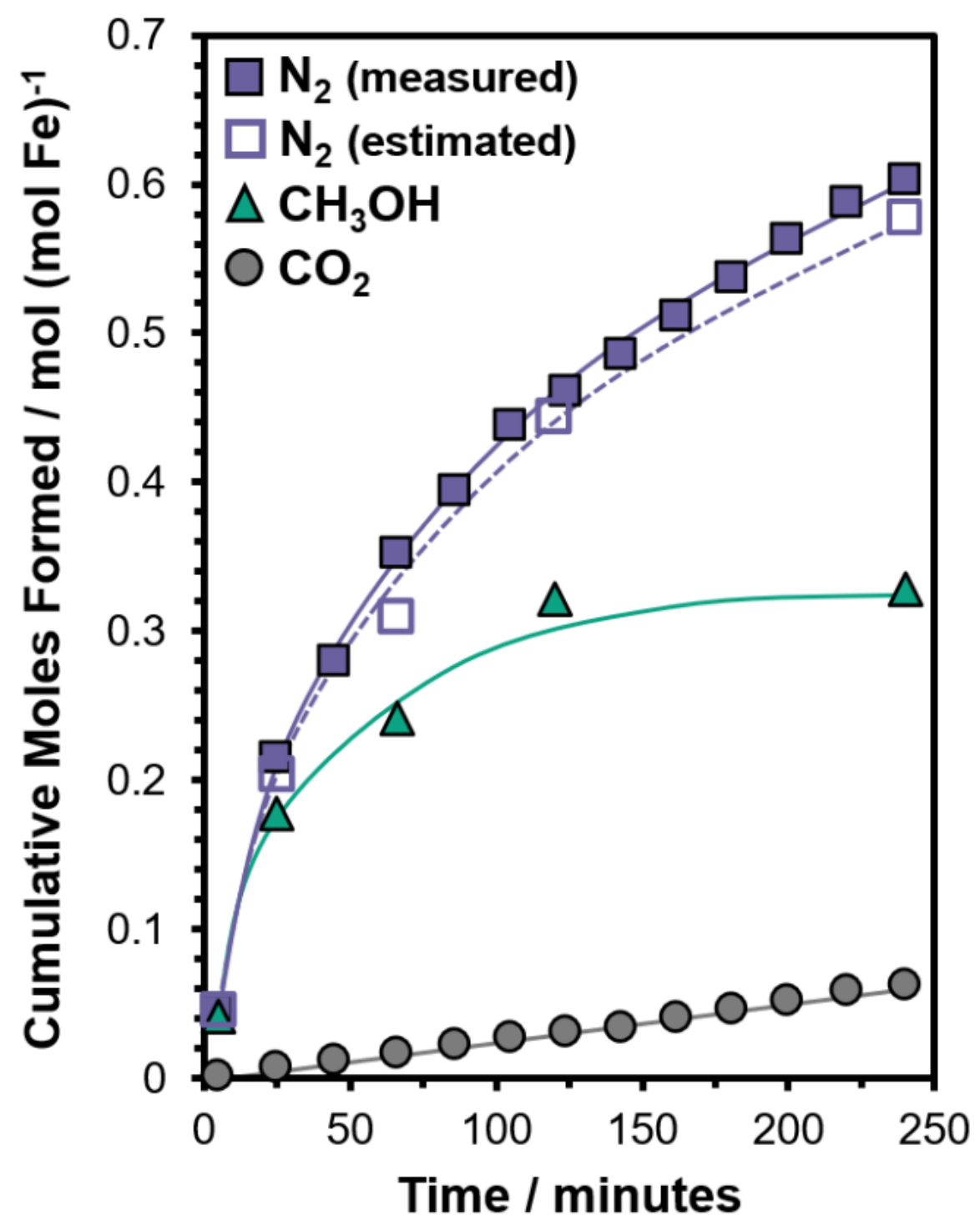

Figure 1. Cumulative moles of $\mathrm{N}_{2}, \mathrm{CO}_{2}$, and $\mathrm{CH}_{3} \mathrm{OH}$ formed as a function of time of exposure to $\mathrm{CH}_{4}$ and $\mathrm{N}_{2} \mathrm{O}$. The quantity of $\mathrm{CH}_{3} \mathrm{OH}$ reported is that formed upon extraction with water subsequent to $\mathrm{CH}_{4} / \mathrm{N}_{2} \mathrm{O}$ exposure. The estimated quantity of $\mathrm{N}_{2}$ formed was determined by the balance of $\mathrm{CH}_{3} \mathrm{OH}$ and $\mathrm{CO}_{2}$ formed $\left[\left(\mathrm{mol} \mathrm{N}_{2}\right)=\left(\mathrm{mol} \mathrm{CH}_{3} \mathrm{OH}\right)+4\left(\mathrm{~mol} \mathrm{CO}_{2}\right)\right]$ Reaction conditions: $2.9 \mathrm{kPa} \mathrm{N} \mathrm{N}_{2}, 1.5 \mathrm{kPa} \mathrm{CH}_{4}, 0.35 \mathrm{kPa} \mathrm{H}_{2} \mathrm{O}$, $473 \mathrm{~K}, \mathrm{MIL}-100(\mathrm{Fe})$ activated at $523 \mathrm{~K}$.

The invariance in $\mathrm{CO}_{2}$ formation rates with time despite the consumption of $\mathrm{Fe}^{2+}$ sites converting methane to methanol indicates that $\mathrm{Fe}^{2+}$ site densities that allow for the rigorous normalization of methanol formation, do not do so for $\mathrm{CO}_{2}$ formation, and suggests an independence between sites responsible for the formation 
of these two products. Moreover, unlike methanol formation, which can be completely inhibited by the presence of gas phase $\mathrm{NO}$ under reaction conditions, the formation of $\mathrm{CO}_{2}$ is unaffected by the presence of $\mathrm{NO}$, as reflected by the insensitivity of cumulative $\mathrm{CO}_{2}$ formation to the presence of $\mathrm{NO}$ co-feeds (Figure 2a). Reported cumulative moles of $\mathrm{CO}_{2}$ formed are corrected for those measured when $\mathrm{NO}$ was flown over MIL-100(Fe) in the absence of methane and $\mathrm{N}_{2} \mathrm{O}\left(0.0035 \mathrm{~mol}(\mathrm{~mol} \text { total } \mathrm{Fe})^{-1}\right)$. Such NO-induced oxidation (presumably of the MIL-100 framework) accounts accurately for the slight increase in $\mathrm{CO}_{2}$ formation upon introduction of $\mathrm{NO}$ with methane and $\mathrm{N}_{2} \mathrm{O}(0.0039 \mathrm{~mol} \text { (mol total } \mathrm{Fe})^{-1}$, Table S4), and suggests that linker oxidation rates are unaffected by the presence of methane and $\mathrm{N}_{2} \mathrm{O}$. The insensitivity in cumulative $\mathrm{CO}_{2}$ formation rates to $\mathrm{Fe}^{2+}$ site densities both in the presence and absence of NO suggest that a significant fraction of $\mathrm{CO}_{2}$ formation may occur over a distinct set of sites compared to those identified for methanol formation.

Given the near complete absence of $\mathrm{NO}$ adsorption onto $\mathrm{Fe}^{3+}$ sites under reaction conditions and the insensitivity of $\mathrm{CO}_{2}$ formation rates to the presence of $\mathrm{NO}$ in the gas phase, their involvement in $\mathrm{CO}_{2}$ formation warrants further evaluation- a question that is challenging to definitively address in the absence of titrants that bind exclusively to $\mathrm{Fe}^{3+}$ sites (and not $\mathrm{Fe}^{2+}$ sites). A clue as to the involvement of $\mathrm{Fe}^{3+}$ sites in $\mathrm{CO}_{2}$ formation is provided by water titrations $\left(0.9 \mathrm{kPa} \mathrm{H}_{2} \mathrm{O}\right.$ at $\left.423 \mathrm{~K}\right)$ that bind unselectively to open-metal sites regardless of their oxidation state, as indicated by the adsorption of one mole water per mol iron under conditions of interest (Figure S8). Whereas co-feeding $\mathrm{NO}$ eliminates (solely) $\mathrm{CH}_{3} \mathrm{OH}$ formation, introduction of $\mathrm{H}_{2} \mathrm{O}$ with methane and $\mathrm{N}_{2} \mathrm{O}\left(14.5 \mathrm{kPa} \mathrm{N} \mathrm{N}_{2} \mathrm{O}, 1.5 \mathrm{kPa} \mathrm{CH}_{4}, 0.9 \mathrm{kPa} \mathrm{H} \mathrm{H}_{2} \mathrm{O}\right)$ results in the complete elimination of both oxidation products (Figure 2a). Additionally, the presence of $0.5 \mathrm{kPa} \mathrm{NO}$ in the gas phase causes the introduction of increasing $\mathrm{H}_{2} \mathrm{O}$ partial pressures $(0.1-0.9 \mathrm{kPa})$ to result in a systematic increase in the total quantity of water adsorbed, and a concurrent linear decrease in cumulative moles of $\mathrm{CO}_{2}$ formed with increasing amount of water adsorbed (Figure $2 \mathrm{~b}$ ). The linear relationship between the cumulative moles of $\mathrm{CO}_{2}$ formed and those of water adsorbed reflects a constant ratio between the number of sites that adsorb water and those eliminated from participation in $\mathrm{CO}_{2}$ formation. Moreover, the quantity of water adsorption required to completely suppress $\mathrm{CO}_{2}$ formation was found to be $0.62 \mathrm{~mol}$ (total mol $\mathrm{Fe})^{-1}$ - a value approximately equal to the concentration of $\mathrm{Fe}^{3+}$ open-metal sites $\left(0.65 \mathrm{~mol}(\text { total mol } \mathrm{Fe})^{-1}\right)$ measured independently using $\mathrm{D}_{2} \mathrm{O}$ adsorption measurements (Section S2.5, SI).

(a)

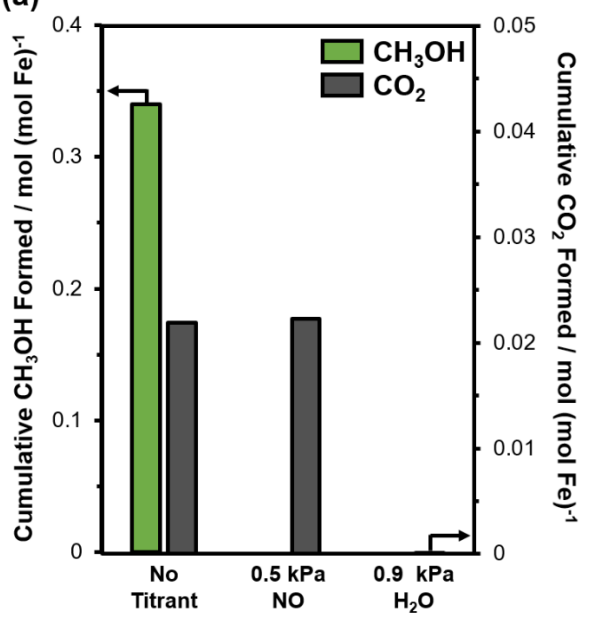

(b)

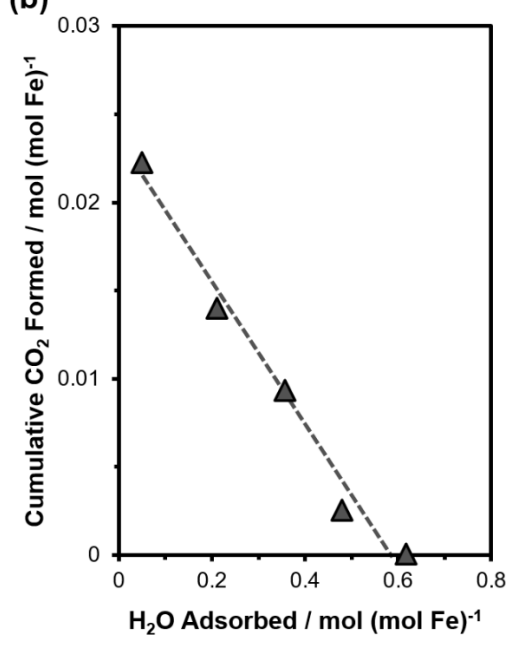

Figure 2. (a) Cumulative moles of methanol (left axis) and $\mathrm{CO}_{2}$ (right axis) formed per total Fe in the absence of any titrant and in the presence of $\mathrm{NO}(0.5 \mathrm{kPa})$ or $\mathrm{H}_{2} \mathrm{O}(0.9 \mathrm{kPa})$. (b) Under $0.5 \mathrm{kPa} \mathrm{NO}$, the quantity of $\mathrm{H}_{2} \mathrm{O}$ adsorbed in MIL-100(Fe) over a range of partial pressures $(0.1-0.9 \mathrm{kPa})$ and the cumulative moles of $\mathrm{CO}_{2}$ formed per total $\mathrm{Fe}$ under that condition. Reaction conditions: $423 \mathrm{~K}, 14.5 \mathrm{kPa} \mathrm{N} \mathrm{N}_{2} \mathrm{O}, 1.5 \mathrm{kPa}$ $\mathrm{CH}_{4}, \mathrm{t}=2 \mathrm{~h}$, activated at $523 \mathrm{~K}$ for $12 \mathrm{~h}$ in $\mathrm{He}$. 
Thermal treatment protocols can be used to access increasing densities of $\mathrm{Fe}^{2+}$ and $\mathrm{Fe}^{3+}$ sites, ${ }^{35,43,52}$ with activation temperatures below $423 \mathrm{~K}$ yielding a majority of $\mathrm{Fe}^{3+}$ sites, and those above $423 \mathrm{~K}$ resulting in the formation of $\mathrm{Fe}^{2+}$ sites in addition to $\mathrm{Fe}^{3+}$ sites (Table S3). Cumulative $\mathrm{CO}_{2}$ yields normalized by the density of $\mathrm{Fe}^{3+}$ sites remain nearly invariant in activation temperature, unlike those normalized by total iron content which increase monotonically with activation temperature (Figure 3), consistent with the involvement of the former in $\mathrm{CO}_{2}$ formation. Also consistent with the sole involvement of $\mathrm{Fe}^{3+}$ sites is the monotonically decreasing trend of $\mathrm{CO}_{2}$ formation rates per $\mathrm{Fe}^{2+}$ site with activation temperature, expected to result from greater relative contributions of $\mathrm{Fe}^{3+}$ sites to the total open-metal site density at higher temperatures (Figure S9). Overall, $\mathrm{CO}_{2}$ cumulative yields that increase linearly with time and are unaffected by decreasing $\mathrm{Fe}^{2+}$ site densities, the insensitivity of $\mathrm{CO}_{2}$ formation rates to $\mathrm{NO}$ pressure, a linear correlation between the amount of water adsorbed in the presence of $\mathrm{NO}$ and cumulative $\mathrm{CO}_{2}$ yields, the precise correspondence between the moles of water required to saturate $\mathrm{Fe}^{3+}$ sites and those required for the complete elimination of $\mathrm{CO}_{2}$ formation, and the invariance in $\mathrm{Fe}^{3+}$-normalized cumulative $\mathrm{CO}_{2}$ yields with increasing thermal activation temperature are all consistent with and suggestive of the involvement of $\mathrm{Fe}^{3+}$ sites in $\mathrm{CO}_{2}$ formation, even though these data do not help definitively exclude the possibility that a minute amount of extraframework iron may be responsible for the same.

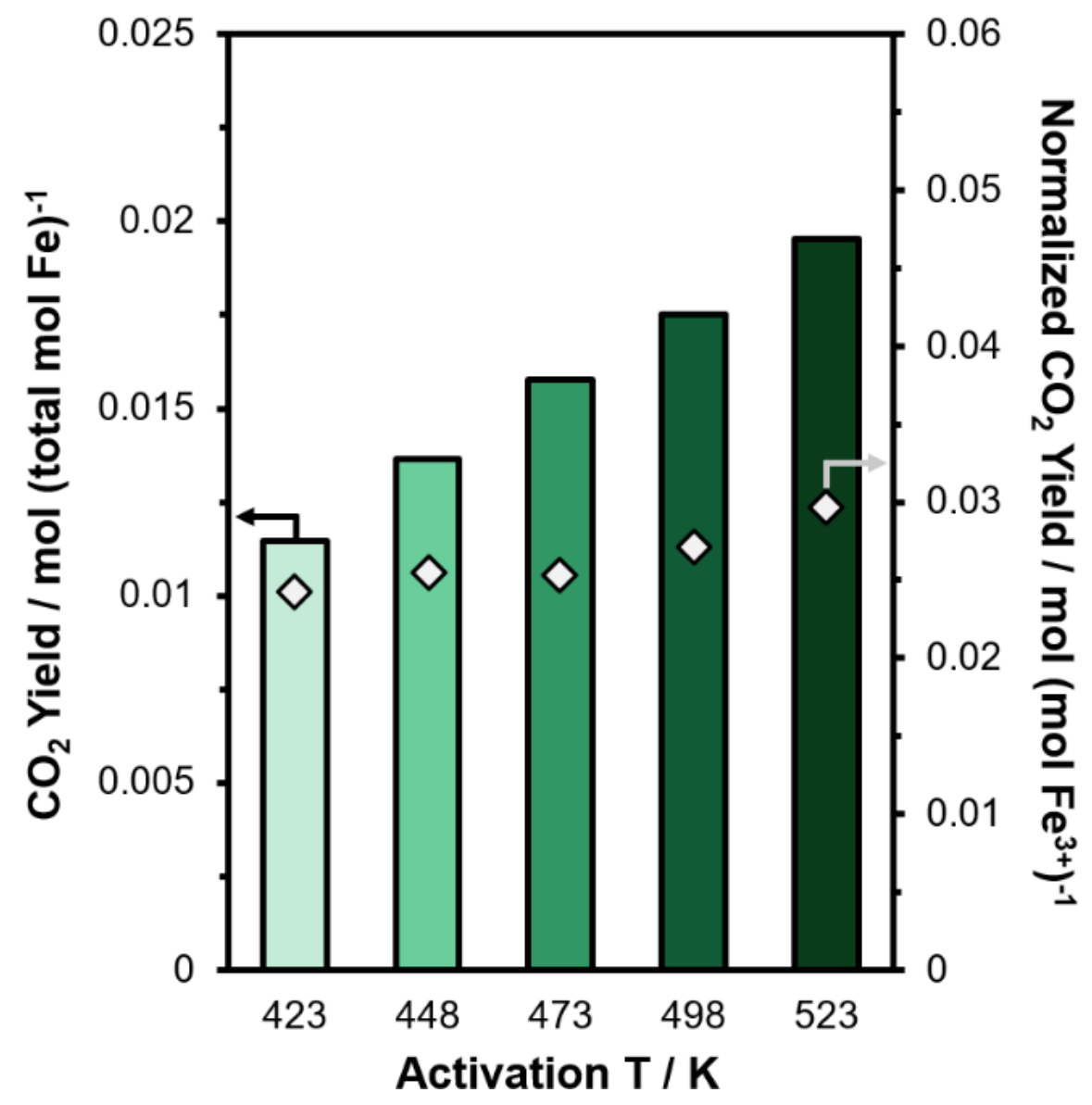

Figure 3. Cumulative moles of $\mathrm{CO}_{2}$ formed normalized by the total iron content (left axis) and per $\mathrm{Fe}^{3+}$ open-metal site (right axis) with increasing activation temperature (423-523 K). Reaction conditions: 473 $\mathrm{K}, 14.5 \mathrm{kPa} \mathrm{N} \mathrm{N}_{2}, 1.5 \mathrm{kPa} \mathrm{CH}_{4}, \mathrm{t}=2 \mathrm{~h}$, activated at temperature for $12 \mathrm{~h}$ in He.

Gagliardi, Snurr, and co-workers have reported density functional theory (DFT)-derived energy profiles for the decomposition of $\mathrm{N}_{2} \mathrm{O}$ over $\mathrm{M}^{2+}$ sites to form $\mathrm{M}(\mathrm{IV})=\mathrm{O}$ species; ${ }^{39,40,53}$ crucially, calculations reported 
by Barona and Snurr suggest the potential for $\mathrm{M}^{3+}$ coordinatively unsaturated sites situated in trimeric MOF nodes to participate in methane oxidation with $\mathrm{N}_{2} \mathrm{O} \cdot{ }^{54}$ For example, a $\mathrm{V}^{3+}$ open-metal site in the $\left(\mathrm{Ni}^{2+}\right)\left(\mathrm{V}^{3+}\right)_{2}$ mixed-metal node was proposed to be oxidized by $\mathrm{N}_{2} \mathrm{O}$ to $\mathrm{Ni}^{2+}\left(\mathrm{V}^{4+}=\mathrm{O}\right) \mathrm{V}^{4+}$, with both of the trivalent vanadium centers donating electrons to form the oxo intermediate. $\mathrm{N}_{2} \mathrm{O}$ activation barriers over $\mathrm{Fe}^{3+}$ open-metal sites in $\left[\left(\mathrm{Cr}^{2+}\right)\left(\mathrm{Fe}^{3+}\right)_{2}\right]$ and $\left[\left(\mathrm{Mn}^{2+}\right)\left(\mathrm{Fe}^{3+}\right)_{2}\right]$ mixed-metal nodes $(144$ and $146 \mathrm{~kJ}$ mol-1, respectively) were found to be comparable to those predicted for $\mathrm{Fe}^{2+}$ open-metal sites on an $\left(\mathrm{Fe}^{2+}\right)\left(\mathrm{Fe}^{3+}\right)_{2}$ node $\left(146 \mathrm{~kJ} \mathrm{~mol}^{-1}\right)$. The involvement of $\mathrm{Fe}^{3+}$ sites in methane oxidation may proceed through the involvement of metal-oxo bond formation steps of such a nature, and a fuller understanding of these steps may require knowledge of changes in formal oxidation states over the entire trimer rather than merely one of three metal atoms constituting the node.

\subsection{The key role of methoxy intermediates in methane conversion}

The absence of gas phase methanol at the reactor outlet during both the methane-nitrous oxide co-feed step as well as the ensuing purge step under inert, but its detection upon exposing the sample to water vapor during the extraction step suggests one of two possibilities: a) water displaces adsorbed methanol through competitive adsorption, or b) reacts with a persistent intermediate formed upon exposure to methane and $\mathrm{N}_{2} \mathrm{O}$ to form gas phase methanol. Exposure to $\mathrm{D}_{2} \mathrm{O}$ (as opposed to $\mathrm{H}_{2} \mathrm{O}$ ) allows for a differentiation between these two scenarios. Whereas the displacement of adsorbed methanol by water should result in the exclusive detection of non-deuterated methanol, incorporation of deuterium into the methanol product would be indicative of the formation of a persistent intermediate that undergoes steps involving the exchange of deuterium from water. Exposure to $\mathrm{D}_{2} \mathrm{O}$ was found to result exclusively in the formation of monodeuteromethanol (Figure 4a), consistent with the formation of methoxy intermediates that then undergo reaction with water to form methanol and reform the hydroxyl anion that was eliminated to create the $\mathrm{Fe}^{2+}$ site in the first place. The fraction of mono-deuteromethanol in the product tracks with the fraction of $\mathrm{D}_{2} \mathrm{O}$ in $\mathrm{H}_{2} \mathrm{O}-\mathrm{D}_{2} \mathrm{O}$ mixtures that the methoxy-covered surface is exposed to (Figure $4 \mathrm{~b}$ ), suggesting a lack of preferential incorporation of hydrogen versus deuterium into the methanol product. Exposure to $\mathrm{H}_{2}{ }^{18} \mathrm{O}$ yielded exclusively $\mathrm{CH}_{3}{ }^{16} \mathrm{OH}$ (Figure $4 \mathrm{c}$ ), consistent with the formation of methoxy intermediates that desorb subsequent to bond formation between methoxy oxygens and hydrogens/deuteriums in water. These data suggest that a significant fraction of the methane converted form methoxy intermediates which are then extracted using water vapor, and are inconsistent with the formation of adsorbed methanol that is subsequently displaced by water.
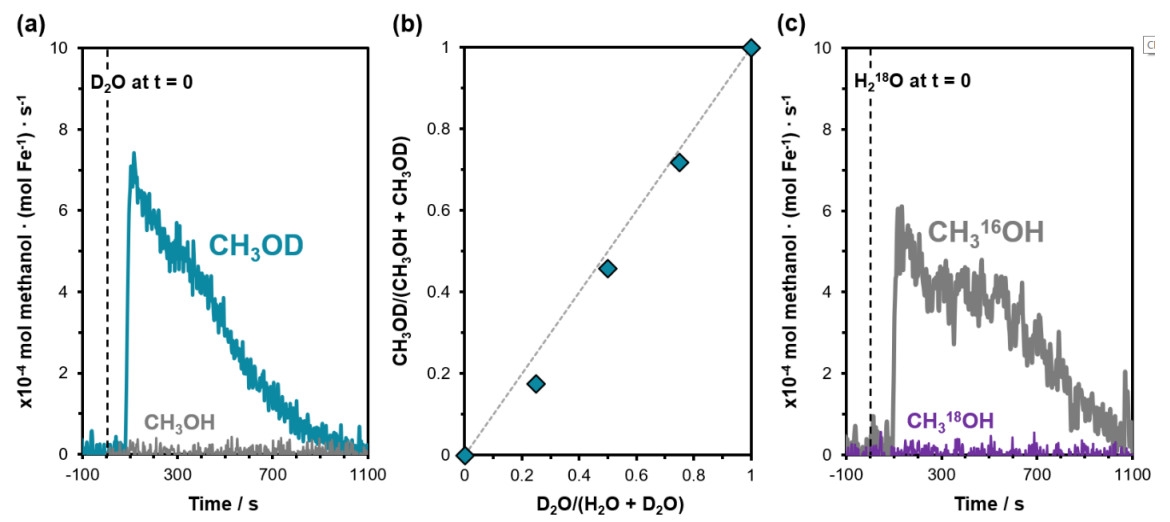

Figure 4. (a) Molar formation rate (per total $\mathrm{Fe}$ ) of $\mathrm{CH}_{3} \mathrm{OH}$ and $\mathrm{CH}_{3} \mathrm{OD}$ formed over MIL-100(Fe) when exposed to $\mathrm{D}_{2} \mathrm{O}$ at $473 \mathrm{~K}$ following reaction. (b) Effect of the molar ratio of $\mathrm{H}_{2} \mathrm{O}$ and $\mathrm{D}_{2} \mathrm{O}$ fed during the product extraction step on the relative amount of $\mathrm{CH}_{3} \mathrm{OH}$ and $\mathrm{CH}_{3} \mathrm{OD}$ formed. (c) Molar formation rate (per total $\mathrm{Fe}$ ) of $\mathrm{CH}_{3}{ }^{16} \mathrm{OH}$ and $\mathrm{CH}_{3}{ }^{18} \mathrm{OH}$ over MIL-100(Fe) when exposed to $\mathrm{H}_{2}{ }^{18} \mathrm{O}$ at $473 \mathrm{~K}$ following reaction. (1.6 kPa N $2 \mathrm{O}, 1.5 \mathrm{kPa} \mathrm{CH}_{4}, 473 \mathrm{~K}, 2 \mathrm{~h}$ ). Figure $4 \mathrm{~b}$ reproduced from ref. ${ }^{35}$ Copyright (C) 2020 WILEY-VCH Verlag GmbH \& Co. KGaA, Weinheim. 
Reaction with water to form methanol from intermediates that are not desorbed from the surface in the absence of water mirrors several observations reported in prior literature. Ethane oxidation over MOF$74(\mathrm{Mg}, \mathrm{Fe})$ to produce ethanol, acetaldehyde, and diethyl ether required extraction with $\mathrm{CD}_{3} \mathrm{CN}_{\text {following }}$ reaction at $348 \mathrm{~K} .{ }^{36}$ Propane/ethane oxidation over MIL-100(Fe) also required oxygenated products to be extracted with $\mathrm{D}_{2} \mathrm{O}$, with only unsaturated ethene/propene products desorbing into the gas phase in the absence of $\mathrm{D}_{2} \mathrm{O} .{ }^{39}$ DFT calculations reported by Vitillo et al. evaluating the radical rebound mechanism for methanol formation suggest that the step involving formation of the $\mathrm{Fe}(\mathrm{IV})=\mathrm{O}$ intermediate over MIL$100(\mathrm{Fe})$ carries the highest activation barrier $\left(140.5 \mathrm{~kJ} \mathrm{~mol}^{-1}\right) .{ }^{40}$ The authors suggest that alcohol desorption may not readily occur under reaction conditions due to the high activation barrier for the desorption for methanol $\left(91.5 \mathrm{~kJ} \mathrm{~mol}^{-1}\right)$ in comparison to the heat of adsorption of $\mathrm{N}_{2} \mathrm{O}\left(30 \mathrm{~kJ} \mathrm{~mol}^{-1}\right)$. A competing pathway to radical rebound to form the surface bound methanol product is one in which the radical dissociates from the active center. ${ }^{55,56}$ The activation energy for radical desorption from Fe nodes in MIL-100(Fe) MOFs was predicted to be only slightly greater ( $5 \mathrm{~kJ} \mathrm{~mol}^{-1}$ greater) than the barrier for radical rebound. ${ }^{40}$ We note in this context that experimental evidence for catalyticmethane hydroxylation over MIL-100(Fe) has not yet been reported in the literature. Though methoxy intermediates are identified in our study as the predominant species formed prior to exposure to water vapor, the identity of elementary steps that form them remain unclear, and the possibility of minor quantities of methanol being formed is challenging to disprove given the plausibility of methanol reacting with open-metal iron sites, as demonstrated in the discussion that follows.

To test for the plausibility of methoxy formation mediated by either adsorbed or gas phase methanol, thermally-activated MIL-100(Fe) was first exposed to $\mathrm{CH}_{3} \mathrm{OH}$ at $373 \mathrm{~K}$, purged for $6 \mathrm{~h}$ under inert flow at $473 \mathrm{~K}$ to remove excess $\mathrm{CH}_{3} \mathrm{OH}$, and then exposed to $\mathrm{D}_{2} \mathrm{O}$. 0.23 mol $\mathrm{CH}_{3} \mathrm{OD}$ (mol Fe) ${ }^{-1}$ were measured upon introduction of $\mathrm{D}_{2} \mathrm{O}$ subsequent to exposure to methanol, a value coinciding closely with that formed following reaction with methane and $\mathrm{N}_{2} \mathrm{O}\left(0.27\right.$ mol $\left.\mathrm{CH}_{3} \mathrm{OD}(\mathrm{mol} \mathrm{Fe})^{-1}\right)$ - Figure 5- evidencing the plausibility of methoxy formation through methanol dissociation over $\mathrm{Fe}^{2+}$ sites. The methanol dissociation observed is analogous to water reacting with open-metal sites to reform hydroxyl anions that have to be eliminated during thermal activations steps in MIL-100(Fe) (Figure S11, SI), as also reported previously over Cr ${ }^{2+}$ sites in MIL-100(Cr). ${ }^{45}$ The susceptibility of methanol towards dissociation over $\mathrm{Fe}^{2+}$ sites suggests that the formation of methanol intermediates in our experiments cannot be excluded. Regardless of the identity of steps mediating methoxy formation, its stoichiometric formation exclusively over $\mathrm{Fe}^{2+}$ sites appears to precede methanol formation upon extraction with water vapor. A 1:1 correspondence between methoxy concentrations and $\mathrm{Fe}^{2+}$ site densities across a range of thermal activation conditions ${ }^{35}$ suggests that methoxy formation involves the participation of only one active center, and contrasts with prior reports for ironexchanged zeolites that propose the involvement of two active ' $\alpha$-oxygen' sites per methoxy formed $\left(\mathrm{CH}_{4}+\right.$ $\left.2(\mathrm{O})_{\alpha}-(\mathrm{OH})_{\alpha}+\left(\mathrm{OCH}_{3}\right)_{\alpha}\right) \cdot{ }^{57,58}$ 


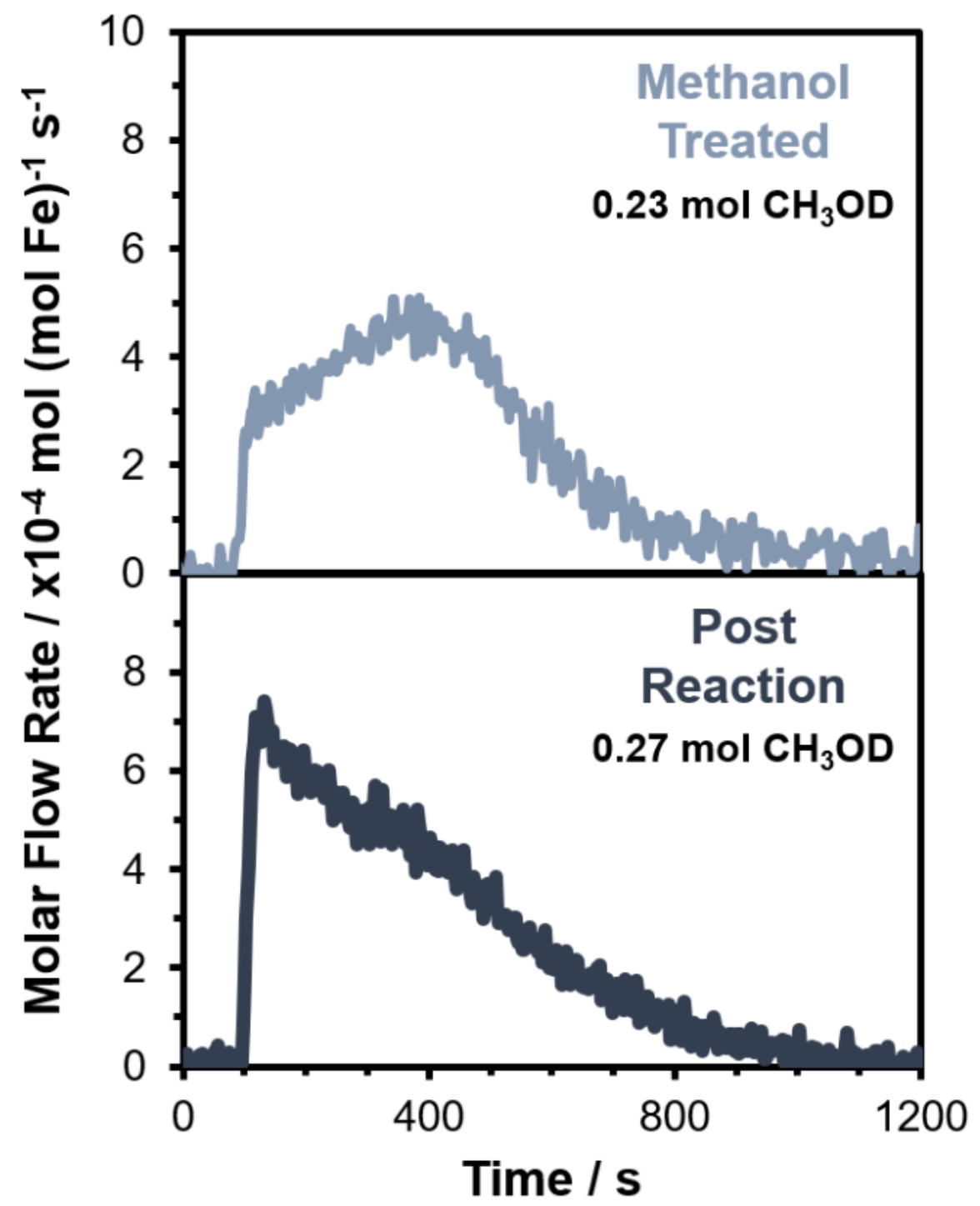

Figure 5. Molar flow rate (per total $\mathrm{Fe}$ ) of $\mathrm{CH}_{3} \mathrm{OD}$ when $\mathrm{D}_{2} \mathrm{O}(0.4 \mathrm{kPa})$ is introduced after the following procedures: (Top) MIL-100(Fe) exposed to $\mathrm{CH}_{3} \mathrm{OH}$ for $1 \mathrm{~h}$ at $373 \mathrm{~K}$ and then purged with He for $6 \mathrm{~h}$ at 473 $\mathrm{K}$; (Bottom) following exposure to $\mathrm{CH}_{4}$ and $\mathrm{N}_{2} \mathrm{O}$. Reaction conditions: $473 \mathrm{~K}, 1.6 \mathrm{kPa} \mathrm{N} \mathrm{O}_{2} \mathrm{O}, 1.5 \mathrm{kPa} \mathrm{CH}_{4}$, $2 \mathrm{~h}$.

\subsection{Manipulating methoxy reactivity by controlling metal identity}

Implicit in the 1:1 correspondence between $\mathrm{Fe}^{2+}$ site densities and the number of moles of monodeuteromethanol is the lack of secondary reactions between methoxy intermediates and gas phase methanol formed in primary reactions. Over and above this correspondence between active site densities and methanol yield, the absence of $\mathrm{C} 2$ oxygenates in the product stream and the fact that all the methane converted can be accounted for (within error) as methanol formed suggests that $\mathrm{C} 2$ intermediates, if formed over the MIL-100(Fe) surface under the conditions reported here thus far, may account for a minor fraction of converted methane. Extraction of intermediates formed under identical conditions by methane and $\mathrm{N}_{2} \mathrm{O}$ over MIL-100(Cr), however, provides (in addition to the formation of methanol) significant yields of acetaldehyde (fractional molar selectivity $=0.81$, Figure 6a).C3CHmeImplicit RecationRe Analogous to the case of tri-iron clusters, moles of methane converted over MIL-100(Cr) track with $\mathrm{M}^{2+}$ site densities (Figure 6b) estimated 
using infrared peak areas corresponding to the hydroxyl anion (Figure S12), pointing to their sole involvement in $\mathrm{C}-\mathrm{H}$ activation. Cumulative moles of methane reacted per mole $\mathrm{Cr}^{3+}$ do not remain invariant in activation temperature but instead increase with the latter (Figure S13, SI) due to the higher $\mathrm{Cr}^{2+} / \mathrm{Cr}^{3+}$ site ratios and the associated lower inactive open-metal site fractions made available through thermal activation at higher temperatures. $\mathrm{M}^{2+}$ sites therefore participate in the activation of methane over both the iron and chromium variants of MIL-100(M). Although Cr-NO interactions are significantly stronger over $\mathrm{Cr}^{2+}$ sites compared to $\mathrm{Cr}^{3+}$ sites, as shown using $\mathrm{NO}$ adsorption measurements at $303 \mathrm{~K}$ reported in our previous work ${ }^{45}$ in contrast with MIL-100(Fe), insignificant NO adsorption occurs onto $\mathrm{Cr}^{2+}$ open-metal sites at reaction temperatures $(423-473 \mathrm{~K})$, as indicated by NO adsorption breakthrough and IR spectroscopy measurements (Section S2.14, SI). We therefore rely solely on the correspondence between product yields and $\mathrm{Cr}^{2+}$ open-metal site densities to suggest their involvement in methoxy formation, unlike the case of MIL-100(Fe) in which in-situ titrations with NO provided additional corroborating evidence of the same.
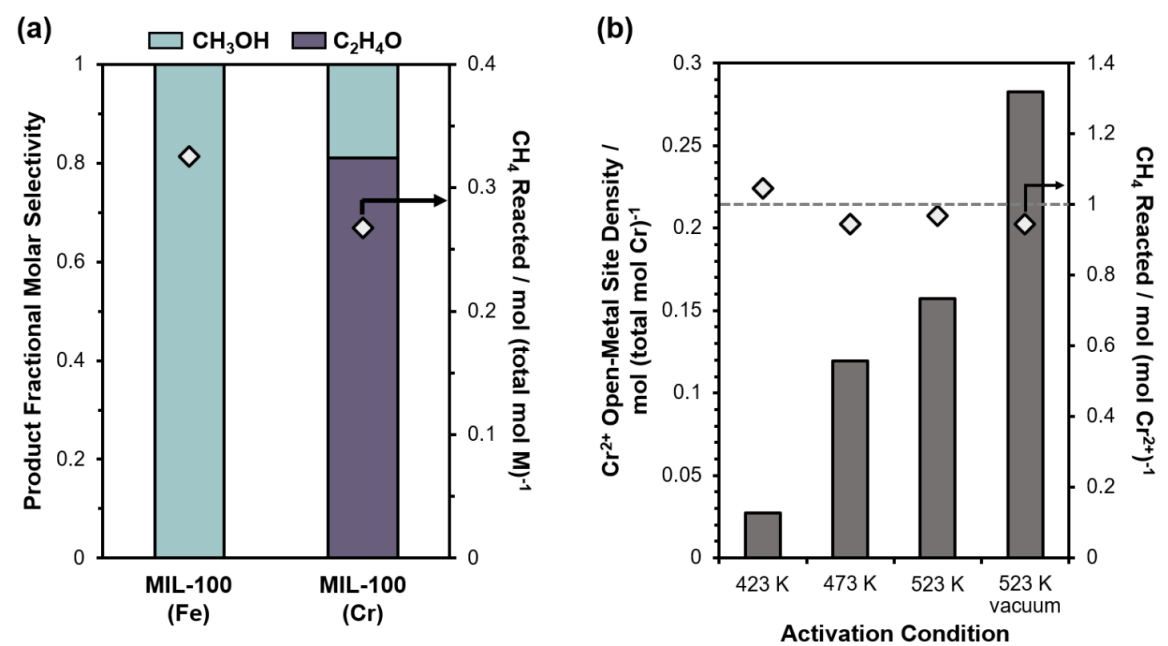

Figure 6. (a) Fractional selectivity for oxygenated products formed during product extraction (473 K, $0.35 \mathrm{kPa} \mathrm{H}_{2} \mathrm{O}, 1.54 \times 10^{-6} \mathrm{~mol} \mathrm{~s}^{-1}$ ) and the quantity of methane reacted (per total mol M) for MIL-100(Fe) and MIL-100(Cr) activated at $523 \mathrm{~K}$ under He flow and in vacuum, respectively. (Reaction conditions: 473 $\mathrm{K}, 2.9 \mathrm{kPa} \mathrm{N} \mathrm{N}_{2} \mathrm{O}, 1.5 \mathrm{kPa} \mathrm{CH}_{4}, 2 \mathrm{~h}$ ). (b) $\mathrm{Cr}^{2+}$ open-metal site densities estimated from IR spectroscopy measurements at various activation conditions and the corresponding cumulative moles of $\mathrm{CH}_{4}$ reacted normalized by the $\mathrm{Cr}^{2+}$ open-metal site density (Reaction conditions: $423 \mathrm{~K}, 14.5 \mathrm{kPa} \mathrm{N} \mathrm{N}_{2}, 1.5 \mathrm{kPa} \mathrm{CH}, 2$ h).

We hypothesize that secondary reactions of methoxy intermediates with gas phase methanol are responsible for acetaldehyde formation. The presence of these secondary reactions prevent the use of $\mathrm{D}_{2} \mathrm{O}$ for evidencing the prevalence of methoxy intermediates over MIL- $100(\mathrm{Cr})$ upon exposure to methane and $\mathrm{N}_{2} \mathrm{O}$. Instead, the prevalence of these secondary reactions can be verified through extraction with $0.12 \mathrm{kPa}$ methanol at $373 \mathrm{~K}$ which leads to the formation, exclusively, of ethanol in both MIL-100(Fe) and MIL-100(Cr) (Figure 7), with the moles of ethanol formed approximating to the $\mathrm{M}^{2+}$ site density for both materials (Table S6, SI). This result is consistent with the same methoxy-covered surface being prevalent in both MIL-100(M) variants following oxidation of $\mathrm{CH}_{4}$, and product distributions detected upon exposure to water vapor being dependent on the differing propensities of $\mathrm{Fe}$ and $\mathrm{Cr}$-methoxy intermediates to undergo $\mathrm{C}-\mathrm{C}$ bond formation steps. It also appears that whereas carbon-carbon bond formation is not predicated on the presence of water vapor, it seems to be necessary for the formation of acetaldehyde (as opposed to ethanol) in MIL$100(\mathrm{Cr})$, as indicated by the observation of methanol and acetaldehyde as products under aqueous extraction conditions (Figure 6a). Both water and methanol appear to be necessary for acetaldehyde formation, as evident in experiments involving extraction using equimolar feeds at $373 \mathrm{~K}$. As a reference condition, a 
temperature of $373 \mathrm{~K}$ and a water partial pressure of $0.12 \mathrm{kPa}$ were chosen for the reason that significant water coverages are attained $\left(0.42 \mathrm{~mol} \mathrm{H}_{2} \mathrm{O} \mathrm{mol} \mathrm{Cr}^{-1}\right)$ in the absence of measurable amounts of methanol or acetaldehyde formation (Figure 8a and Table 1). Co-feeding equimolar mixtures of methanol and water $(0.12 \mathrm{kPa}$ each $)$ under these conditions leads to the formation of 0.93 moles acetaldehyde per mole methane reacted (or equivalently, per mol methoxy formed), evidencing near-complete coupling of methoxies with gas phase methanol. These results suggest that although methoxies can react with methanol in the absence of significant partial pressures of water, the presence of water is necessary for the production of acetaldehyde, rather than ethanol, as the $\mathrm{C} 2$ product, and point to water playing a role in acetaldehyde formation over and above (and may be even independent of) their involvement in primary reaction steps that lead to the formation of gas-phase methanol.
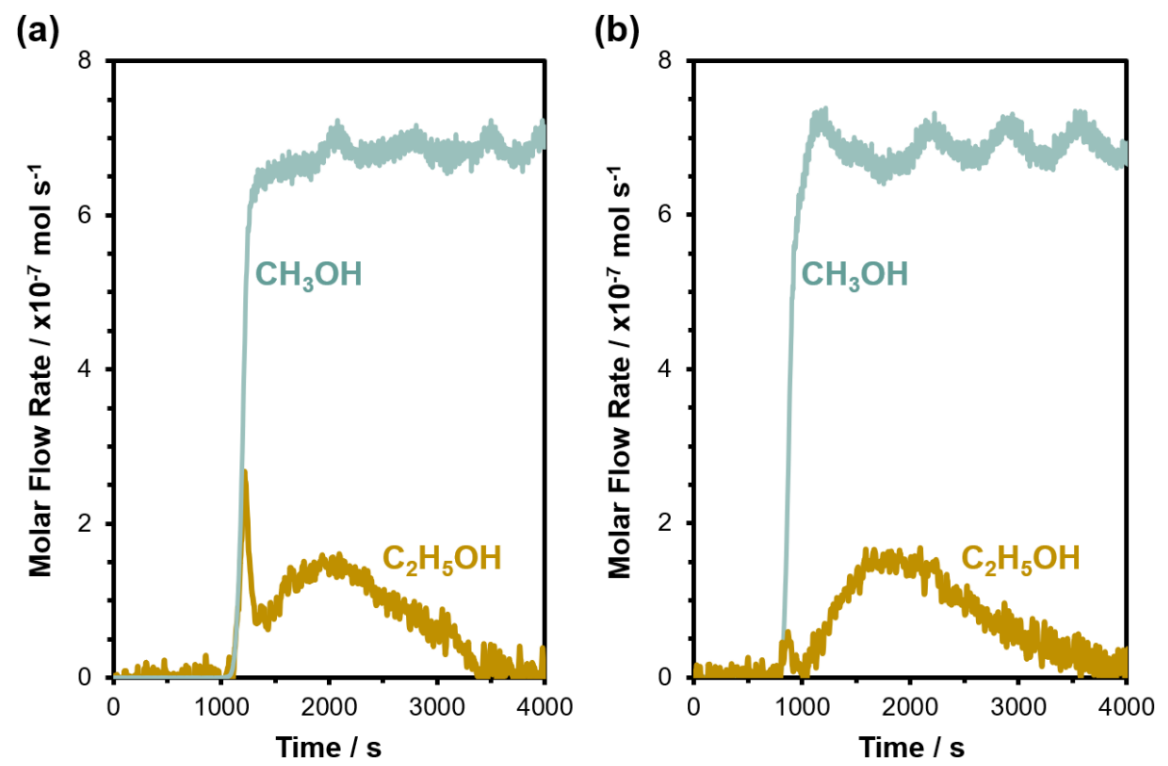

Figure 7. Molar flow rates of $\mathrm{CH}_{3} \mathrm{OH}$ and $\mathrm{C}_{2} \mathrm{H}_{5} \mathrm{OH}$ when $\mathrm{CH}_{3} \mathrm{OH}(0.12 \mathrm{kPa})$ is fed after $\mathrm{CH}_{4}$ oxidation at $373 \mathrm{~K}$ over (a) MIL-100(Cr) and (b) MIL-100(Fe). (Reaction conditions: $473 \mathrm{~K}, 2.9 \mathrm{kPa} \mathrm{N}_{2} \mathrm{O}, 1.5 \mathrm{kPa}$ $\mathrm{CH}_{4}, 2 \mathrm{~h}, \mathrm{MIL}-100(\mathrm{Fe})$ activated at $473 \mathrm{~K}$ under inert flow, MIL-100(Cr) activated at $523 \mathrm{~K}$ in vacuum). 
(a)

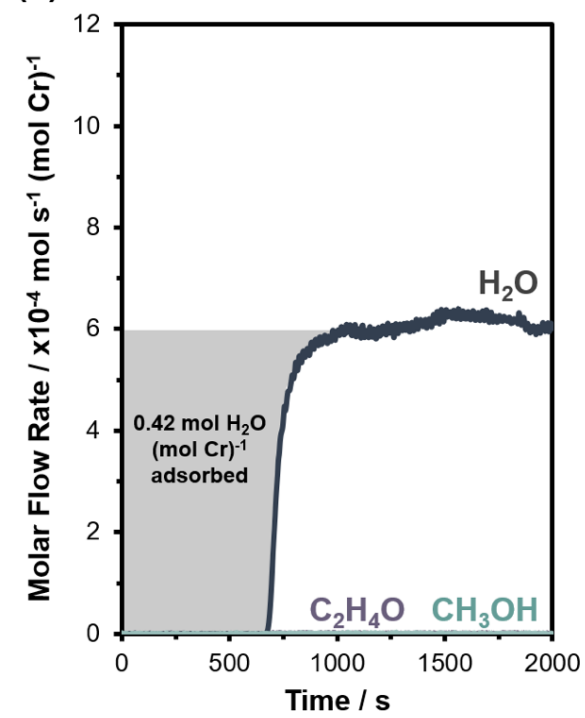

(b)

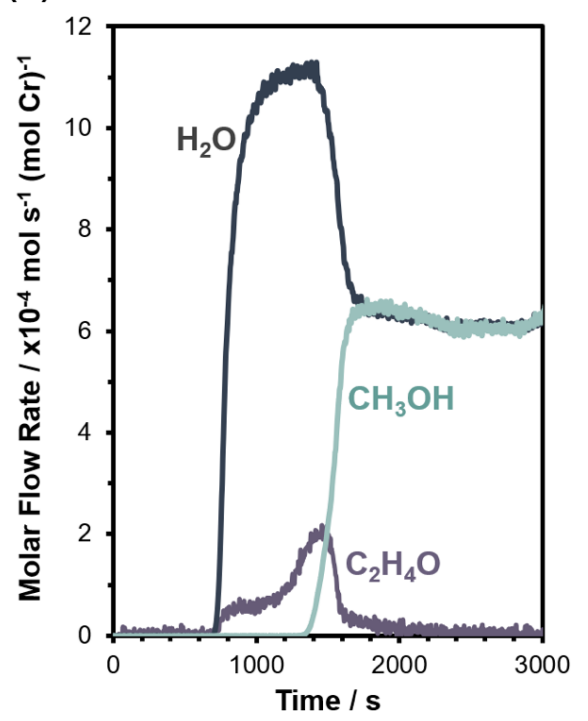

Figure 8. Molar flow rates of $\mathrm{CH}_{3} \mathrm{OH}, \mathrm{H}_{2} \mathrm{O}$, and $\mathrm{C}_{2} \mathrm{H}_{4} \mathrm{O}$ at the reactor outlet as a function of time when either (a) $0.12 \mathrm{kPa} \mathrm{H} \mathrm{H}_{2} \mathrm{O}$ or (b) $0.12 \mathrm{kPa} \mathrm{H}_{2} \mathrm{O}$ and $0.12 \mathrm{kPa} \mathrm{CH}_{3} \mathrm{OH}$ are fed over MIL-100(Cr) at $373 \mathrm{~K}$ following the oxidation of $\mathrm{CH}_{4}$ (reaction conditions: $473 \mathrm{~K}, 2.9 \mathrm{kPa} \mathrm{N} 2 \mathrm{O}, 1.5 \mathrm{kPa} \mathrm{CH}_{4}, 2 \mathrm{~h}$, activated at $523 \mathrm{~K}$ in $\mathrm{He}$ for $12 \mathrm{~h}$ ).

Table 1. Comparison of the cumulative moles of $\mathrm{CH}_{4}$ reacted and $\mathrm{C}_{2} \mathrm{H}_{4} \mathrm{O}$ formed over MIL-100(Cr) when the product extraction step is conducted under different pressures of $\mathrm{H}_{2} \mathrm{O}$ and $\mathrm{CH}_{3} \mathrm{OH}$ at $373 \mathrm{~K} . \mathrm{C}_{2} \mathrm{H}_{4} \mathrm{O}$ to methoxy ratios are determined assuming $1 \mathrm{~mol} \mathrm{CH}_{3} \mathrm{O}$ formed per mol $\mathrm{CH}_{4}$ reacted (Reaction conditions: $473 \mathrm{~K}, 2.9 \mathrm{kPa} \mathrm{N} \mathrm{N}_{2}, 1.5 \mathrm{kPa} \mathrm{CH}, 2 \mathrm{~h}$, activated at $523 \mathrm{~K}$ in $\mathrm{He}$ for $12 \mathrm{~h}$ ). No product formation detected in the presence of only $0.12 \mathrm{kPa} \mathrm{H}_{2} \mathrm{O}$.

\begin{tabular}{|c|c|c|c|c|}
\hline $\begin{array}{l}\mathrm{H}_{2} \mathrm{O} \text { Partial } \\
\text { Pressure / kPa }\end{array}$ & $\begin{array}{l}\mathrm{CH}_{3} \mathrm{OH} \text { Partial } \\
\text { Pressure / kPa }\end{array}$ & $\begin{array}{l}\mathrm{CH}_{4} \text { Reacted / } \\
\text { mol }(\mathrm{mol} \mathrm{M})^{-1}\end{array}$ & $\begin{array}{l}\mathrm{C}_{2} \mathrm{H}_{4} \mathrm{O} \text { Formed / } \\
\mathrm{mol}(\mathrm{mol} \mathrm{M})^{-1}\end{array}$ & $\begin{array}{l}\mathrm{mol} \mathrm{C}_{2} \mathrm{H}_{4} \mathrm{O}(\mathrm{mol} \\
\left.\mathrm{CH}_{3} \mathrm{O}\right)^{-1}\end{array}$ \\
\hline 0.12 & 0 & 0.14 & - & 0 \\
\hline 0.12 & 0.12 & 0.13 & 0.121 & 0.93 \\
\hline
\end{tabular}

The role of water in acetaldehyde formation was investigated further by testing the reactivity of ethanol over activated MIL-100(Cr). Stoichiometric conversion of ethanol was observed at $373 \mathrm{~K}$ over activated MIL$100(\mathrm{Cr})$ in quantities consistent with the density of $\mathrm{Cr}^{2+}$ sites (Table 2 and Figure S15b). Lower activation temperatures that allow for the concurrent presence of $\mathrm{Cr}^{2+}$ and $\mathrm{Cr}^{3+}{ }_{-} \mathrm{OH}^{-}$groups enable acetaldehyde formation in amounts that track with $\mathrm{Cr}^{2+}$ density, but activation under vacuum at $523 \mathrm{~K}$ which creates $\mathrm{Cr}^{2+}$ sites far in excess of terminal hydroxyls $\left(\mathrm{Cr}^{3+}-\mathrm{OH}^{-}\right)$results in a decrease in cumulative acetaldehyde formation (Figure 9). Specifically, cumulative moles of acetaldehyde formed $\left(0.07 \mathrm{~mol}(\mathrm{~mol} \mathrm{Cr})^{-1}\right)$ under this activation condition more closely approximate the moles of terminal hydroxides $\left(0.05 \mathrm{~mol} \mathrm{Cr}^{3+}-\mathrm{OH}^{-}(\mathrm{mol}\right.$ $\left.\mathrm{Cr})^{-1}\right)$ than the moles of reduced metal sites $\left(0.28 \mathrm{~mol} \mathrm{Cr}^{2+}(\mathrm{mol} \mathrm{Cr})^{-1}\right)$, suggesting that while methoxy formation is predicated on the availability of reduced metal sites, terminal hydroxides may be necessary for the dehydrogenation of ethanol to acetaldehyde.

Table 2. For MIL-100(Fe) and MIL-100(Cr), the activation condition employed, the corresponding $\mathrm{M}^{2+}$ site density, and the total quantity of acetaldehyde formed when ethanol $(0.11 \mathrm{kPa})$ is fed over the activated material at $373 \mathrm{~K}$. 


\begin{tabular}{llll}
\hline Material & Activation Condition & $\begin{array}{l}\mathbf{M}^{2+} \text { Site Density / } \\
\text { mol (total mol M) }\end{array}$ & $\begin{array}{l}\mathbf{C}_{2} \mathbf{H}_{4} \text { O Formed / mol } \\
(\text { total mol } \mathbf{M})^{-1}\end{array}$ \\
\hline $\mathrm{Cr}$ & Inert flow, $523 \mathrm{~K}$ & 0.16 & 0.13 \\
$\mathrm{Fe}$ & Inert flow, $423 \mathrm{~K}$ & 0.11 & 0.12 \\
\hline
\end{tabular}

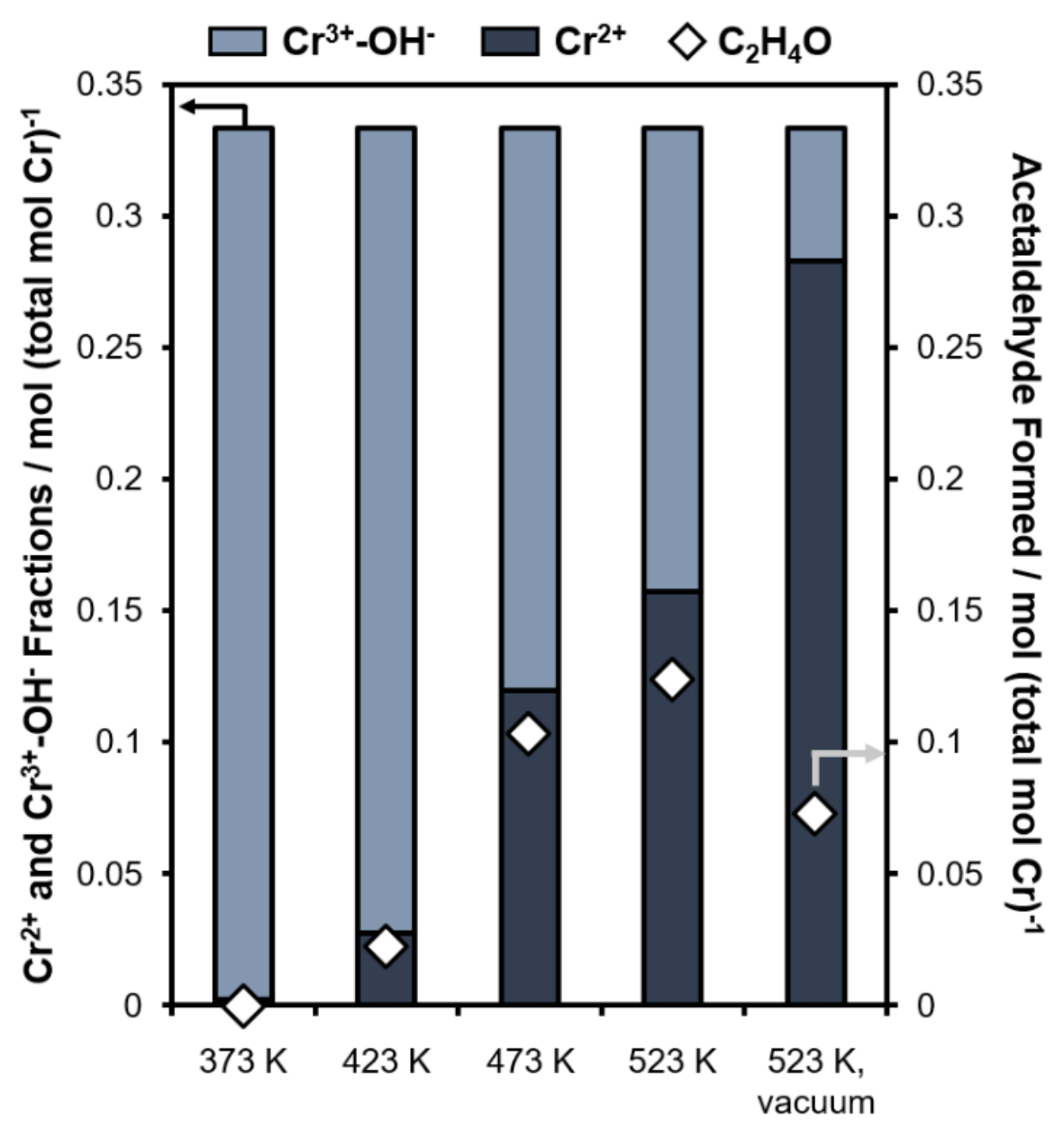

Activation Condition

Figure 9. $\mathrm{Cr}^{2+}$ open-metal and $\mathrm{Cr}^{3+}-\mathrm{OH}^{-}$site densities (left axis) with increasing extent of activation and the corresponding quantity of acetaldehyde formed (right axis) when ethanol $(0.11 \mathrm{kPa})$ is fed over MIL-100(Cr) at $373 \mathrm{~K}$ following thermal activation in He or vacuum (when indicated).

To further investigate the role of water in methane conversion to methanol/acetaldehyde, methoxy extraction was carried out over MIL-100 $(\mathrm{Cr})$ at varying water partial pressures while keeping the total water flow rate constant, and also at varying water flow rates while keeping the water partial pressure constant (Figure 10, Table S7). Regardless of water flow rates and partial pressures, water, methanol, and acetaldehyde break through simultaneously, consistent with methanol formation resulting from primary reactions between surface methoxies and water, and acetaldehyde resulting from secondary reactions between methoxies and gas phase methanol. The primary(/secondary) nature of methanol(/acetaldehyde) is consistent with the water breakthrough time- the time required for the edge of the water concentration front to reach the bottom of the MIL-100(Cr) bed- being identical to the time required for both methanol and acetaldehyde 
to elute through the bed. The rank of products in these stoichiometric reactions is also consistent with the relative sharpness of their concentration fronts; methanol, which breaks through with water, exhibits significantly sharper concentration profiles compared to acetaldehyde (the secondary product), and elutes from the bed exclusively during the period when water molar flow rates at the exit of the bed lie between zero and that at the inlet. In fact, acetaldehyde fronts are broad enough that acetaldehyde is produced through methanol-methoxy interactions long after methanol ceases to be detected at the outlet of the bed (Figure 10).

Water partial pressures not only enable us to tune the relative number of primary (methoxy-water) interactions to secondary (methoxy-methanol) interactions as shown in Figure 10, but also the possibility of water-methoxy interactions in the first place. The stoichiometric nature of both these interactions suggests that under conditions where acetaldehyde is the exclusive product the ratio of moles of acetaldehyde formed to methoxies consumed should lie between 0.5 and 1 , with a ratio of 0.5 indicating that every molecule of acetaldehyde owes its formation to an interaction between a methoxy species with a methanol molecule that is desorbed into the gas phase subsequent to a primary interaction with water (Scheme 2b). A ratio of unity, on the other hand, indicates the exclusive participation in methanol-methoxy interactions of methanol molecules fed at the inlet of the reactor, and the lack of $\mathrm{C}-\mathrm{C}$ bond formation contributions from methanol molecules generated 'in-situ' through water-methoxy interactions (Scheme 2c).

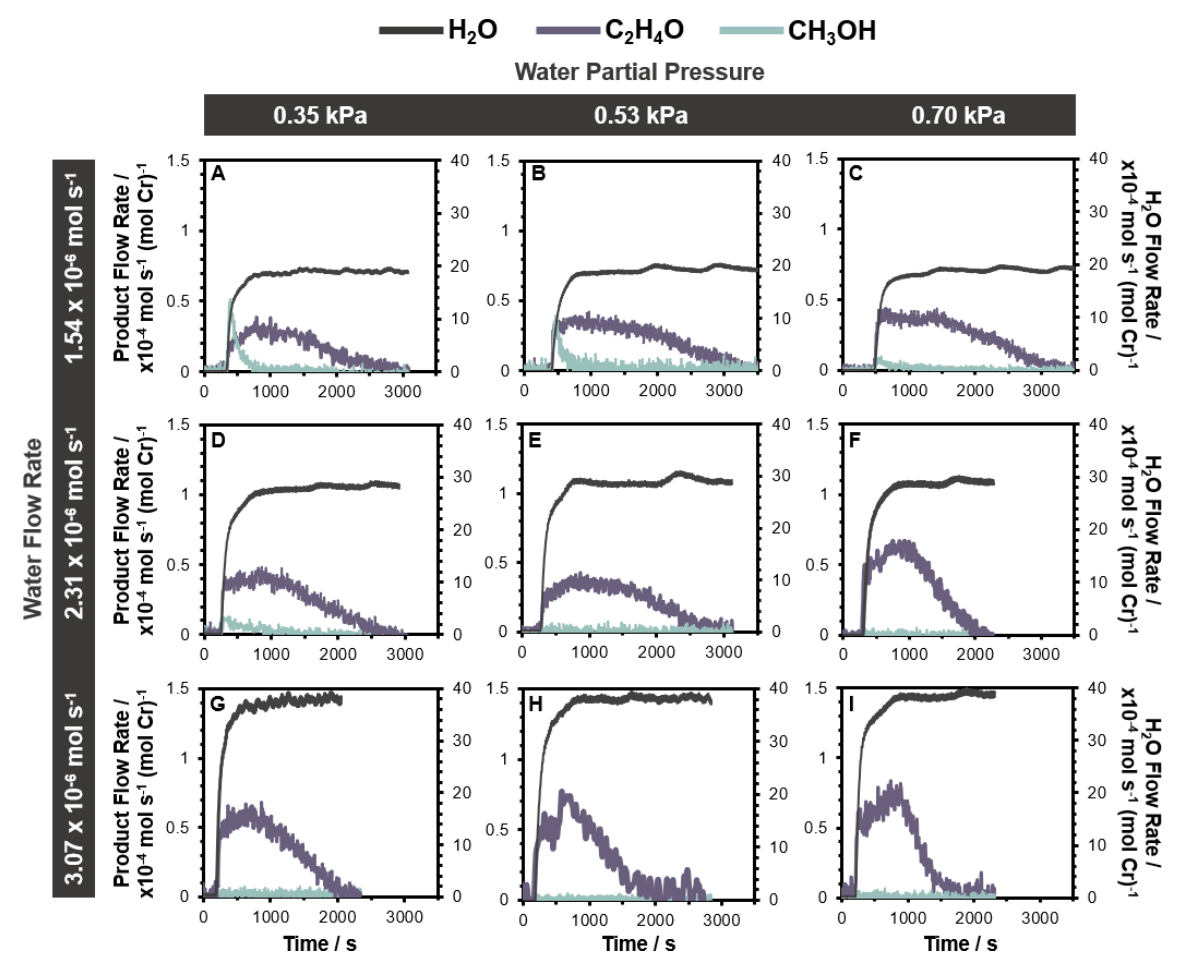

Figure 10. Effect of water partial pressure $(0.35-0.70 \mathrm{kPa})$ and flow rate $\left(1.54-3.07 \times 10^{-6} \mathrm{~mol} \mathrm{H}_{2} \mathrm{O} \mathrm{s}^{-1}\right)$ on the $\mathrm{CH}_{3} \mathrm{OH}$ and $\mathrm{C}_{2} \mathrm{H}_{4} \mathrm{O}$ selectivity over MIL-100 $(\mathrm{Cr})$ as indicated by the molar flow rates detected for both products at the reactor outlet as a function of time. (Extraction at $473 \mathrm{~K}$, Reaction conditions: 473 $\mathrm{K}, 2.9 \mathrm{kPa} \mathrm{N} \mathrm{N}_{2} \mathrm{O}, 1.5 \mathrm{kPa} \mathrm{CH}_{4}, 2 \mathrm{~h}$, activated at $523 \mathrm{~K}$ in $\mathrm{He}$ for $12 \mathrm{~h}$ )

Scheme 2. (a) Representation of the MIL-100 surface following the reaction of $\mathrm{CH}_{4}$ and $\mathrm{N}_{2} \mathrm{O}$ in which 1 mol methoxy is formed per mol $\mathrm{CH}_{4}$ reacted. (b) Formation of acetaldehyde exclusively through the secondary reaction of $\mathrm{CH}_{3} \mathrm{OH}$ molecules formed 'in-situ' (blue) (c) Formation of acetaldehyde exclusively by reaction with $\mathrm{CH}_{3} \mathrm{OH}$ fed at the inlet (black), resulting in the formation of 1 acetaldehyde molecule per methoxy 
consumed.

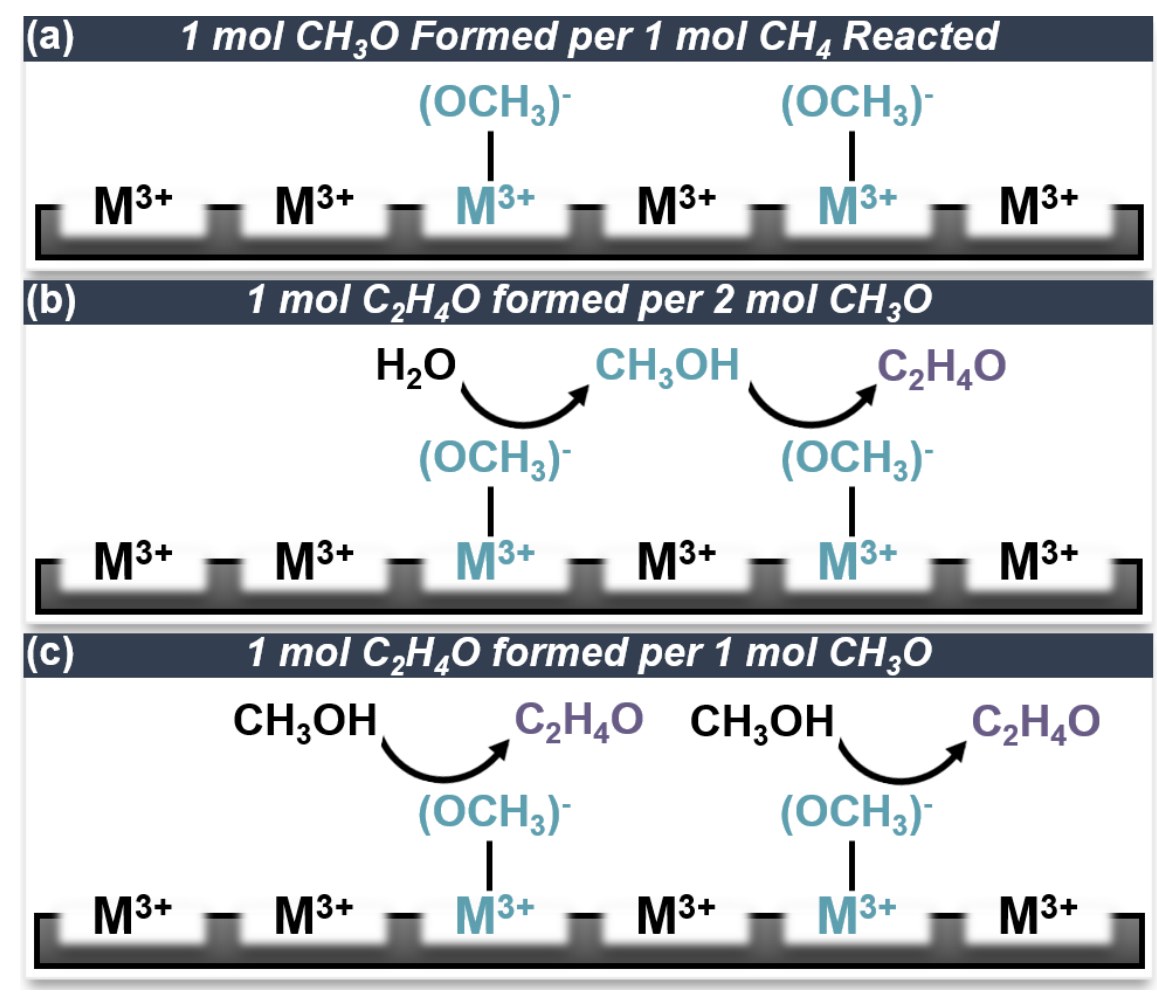

This ratio captures the fraction of methoxies that interact with gas phase methanol of either kind to form acetaldehyde, with larger values indicative of greater relative contributions from methanol fed at the inlet versus those formed in-situ. As expected, acetaldehyde formation:methoxy consumption ratios of 0.5 were observed when the extraction was carried out at $373 \mathrm{~K}$ in the presence of $0.35 \mathrm{kPa}$ water due to the absence of co-fed methanol (Table 3). Interestingly, these ratios were still found to lie in the vicinity of 0.5 when $0.35 \mathrm{kPa}$ methanol was co-fed with $0.35 \mathrm{kPa}$ water, suggesting that fed methanol contributes negligibly toward acetaldehyde formation, which instead results exclusively from $\mathrm{C}-\mathrm{C}$ bond formation events involving methanol generated in-situ. A possible reason for the lack of participation of co-fed methanol may be the significantly slower movement of methanol through the MOF bed compared to water due to methanol outcompeting water from the standpoint of its affinity to open metal sites. Co-fed methanol is precluded from participating in secondary reactions due to the slower movement of its front through the MIL-100(Cr) bed, which results in fed methanol accessing only those regions of the bed that have been already been depleted of methoxies through interactions with the more rapidly progressing water concentration front. Such displacement of water by methanol is consistent with the rollover of water to flow rates exceeding those at the inlet (Figure 8b)- flow rates that likely accelerate the progress of methanol and acetaldehyde fronts generated in-situ. Reducing the water concentration to $0.12 \mathrm{kPa}$ in the absence of co-fed methanol, on the other hand, reduces methanol and acetaldehyde formation rates to values below the detection limit of the mass spectrometer (Figure 8a). Introduction of equimolar water-methanol feeds at these pressures (0.12 kPa each) result in approximately the same number of moles of acetaldehyde formed as methoxies consumed, consistent with the lack of water methoxy interactions at these low water pressures (Table 1). The reaction of methoxies exclusively with methanol (but not water) at identical pressures of each reactant captures the propensity of MIL-100(Cr) to form C-C bonds, and the resulting prevalence of C-C bond formation steps at water pressures lower than those required for methoxy-water interactions. These interactions are significantly more challenging to deconvolute under conditions where $\mathrm{C}-\mathrm{C}$ bond formation can also occur between methoxies and methanol molecules that result from water-methoxy interactions. The data presented 
in Table 3 suggest that exercising precise control over the relative preponderance of water-methoxy and methanol-methoxy interactions is highly non-trivial due to the fact that water-methoxy interactions can an increase local methanol concentrations that in turn make secondary reactions of methanol more probable, and may constitute part of the explanation as to why increasing water partial pressures appear to have an outsized effect on methanol-methoxy interactions compared to water-methoxy interactions (Figure 10).

Table 3. Comparison of the cumulative moles of $\mathrm{CH}_{4}$ reacted and $\mathrm{C}_{2} \mathrm{H}_{4} \mathrm{O}$ formed over MIL-100(Cr) when the product extraction step is conducted under different partial pressures of $\mathrm{H}_{2} \mathrm{O}$ and $\mathrm{CH}_{3} \mathrm{OH}$ at $373 \mathrm{~K}$. $\mathrm{C}_{2} \mathrm{H}_{4} \mathrm{O}$ to methoxy ratios are determined for $1 \mathrm{~mol} \mathrm{CH}_{3} \mathrm{O}$ formed per mol $\mathrm{CH}_{4}$ reacted. (Reaction conditions: $473 \mathrm{~K}, 2.9 \mathrm{kPa} \mathrm{N} 2 \mathrm{O}, 1.5 \mathrm{kPa} \mathrm{CH}_{4}, 2 \mathrm{~h}$, activated at $523 \mathrm{~K}$ in $\mathrm{He}$ for $12 \mathrm{~h}$ ).

\begin{tabular}{|c|c|c|c|c|}
\hline $\begin{array}{l}\mathrm{H}_{2} \mathrm{O} \text { Partial } \\
\text { Pressure / kPa }\end{array}$ & $\begin{array}{l}\mathrm{CH}_{3} \mathrm{OH} \text { Partial } \\
\text { Pressure / kPa }\end{array}$ & $\begin{array}{l}\mathrm{CH}_{4} \text { Reacted / } \\
\mathrm{mol}(\mathrm{mol} \mathrm{M})^{-1}\end{array}$ & $\begin{array}{l}\mathrm{C}_{2} \mathrm{H}_{4} \mathrm{O} \text { Formed / } \\
\mathrm{mol}(\mathrm{mol} \mathrm{M})^{-1}\end{array}$ & $\begin{array}{l}\mathrm{mol} \mathrm{C}_{2} \mathrm{H}_{4} \mathrm{O}(\mathrm{mol} \\
\left.\mathrm{CH}_{3} \mathrm{O}\right)^{-1}\end{array}$ \\
\hline 0.35 & 0 & 0.15 & 0.069 & 0.46 \\
\hline 0.35 & 0.35 & 0.14 & 0.078 & 0.56 \\
\hline
\end{tabular}

\subsection{Prevalence of primary versus secondary reactions over tri-iron nodes}

The ability of MIL-100(Fe) to convert methane to methanol has been reported by multiple groups. As described above, under identical conditions $\left(0.35-0.70 \mathrm{kPa} \mathrm{H} \mathrm{H}_{2} \mathrm{O}, 373-473 \mathrm{~K}\right)$, MIL- $100(\mathrm{Cr})$ exhibits a propensity to convert methane to $\mathrm{C} 2$ oxygenates through secondary interactions of methanol with methoxy species formed on $\mathrm{Cr}^{2+}$ sites. C2 oxygenate formation, however, appears to not necessarily be precluded on MIL$100(\mathrm{Fe})$ materials, as demonstrated by the formation of ethanol upon product extraction with methanol at $0.12 \mathrm{kPa}$ and $373 \mathrm{~K}$ (Figure $7 \mathrm{~b}$ ), and by the formation of acetaldehyde upon feeding ethanol over the partially-dehydrated material (0.11 kPa ethanol, $373 \mathrm{~K}$ - Figure S15a, Table 2). To test whether C2 oxygenate formation could occur over tri-iron clusters upon extraction with water, the water partial pressure during extraction was increased from 0.35 to $1.0 \mathrm{kPa}$ (Figure 11), resulting in the detection of minor amounts of acetaldehyde (fractional molar selectivity $=0.03$ ). Analogous to tri-chromium clusters, increasing inlet water partial pressures can be used to 'force' secondary reactions between $\mathrm{Fe}^{3+}$-methoxies and methanol, but the water partial pressures and/or flow rates required to access meaningful cumulative acetaldehyde selectivities may be much higher on tri-iron nodes than tri-chromium ones. Accessibility to $\mathrm{C} 2$ oxygenate production within lower water partial pressure and flow rate regimes enabled by MIL-100(Cr) likely reflect the greater propensity for $\mathrm{Cr}^{3+}-\mathrm{OCH}_{3}$-intermediates to undergo $\mathrm{C}-\mathrm{C}$ bond formation reactions with gas phase methanol compared to $\mathrm{Fe}^{3+}{ }_{-} \mathrm{OCH}_{3}$ intermediates, and point to metal identity being a reliable lever for tuning product selectivity in the partial oxidation of light alkanes over supported poly-metal oxo clusters. 
(a)

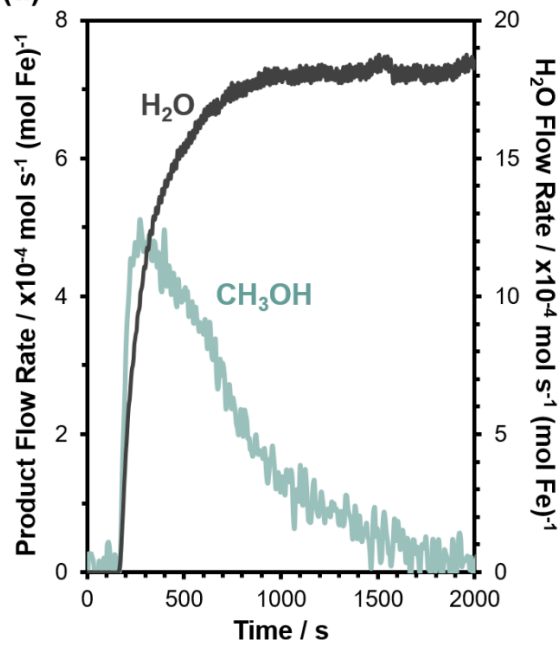

(b)

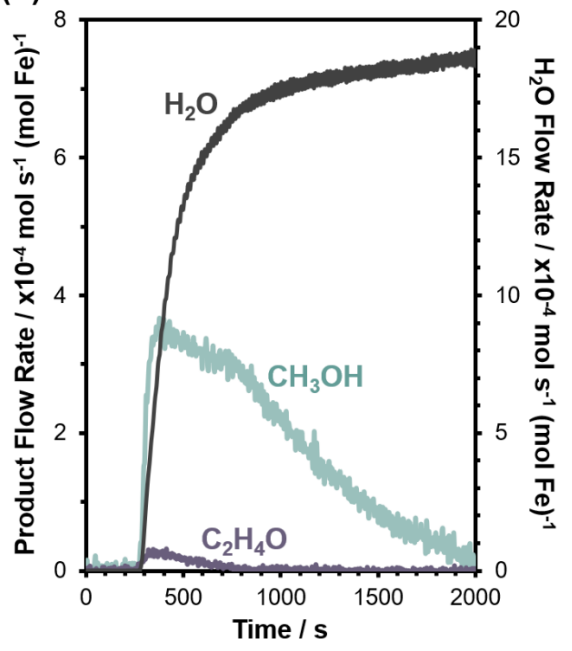

Figure 11. Molar flow rates of $\mathrm{CH}_{3} \mathrm{OH}, \mathrm{H}_{2} \mathrm{O}$, and $\mathrm{C}_{2} \mathrm{H}_{4} \mathrm{O}$ at the reactor outlet as a function of time when (a) $0.35 \mathrm{kPa} \mathrm{H} 2 \mathrm{O}$ or (b) $1.0 \mathrm{kPa} \mathrm{H} \mathrm{H}_{2} \mathrm{O}$ is fed over MIL-100(Fe) at $473 \mathrm{~K}$ following the oxidation of $\mathrm{CH}_{4}$ (reaction conditions: $473 \mathrm{~K}, 2.9 \mathrm{kPa} \mathrm{N} 2 \mathrm{O}, 1.5 \mathrm{kPa} \mathrm{CH}_{4}, 2 \mathrm{~h}$, activated at $523 \mathrm{~K}$ in He for $12 \mathrm{~h}$ ).

\section{Conclusions}

Tri-iron and tri-chromium nodes on MIL-100 frameworks effectuate the conversion of methane to methanol and acetaldehyde at low temperatures and sub-ambient reactant pressures. In-situ titrations with NO over MIL-100(Fe), combined with the equivalence between methoxy densities and $\mathrm{Cr}^{2+}$ open-metal site concentrations in MIL-100(Cr) across a range of thermal activation conditions suggest that the formation of both products occurs solely over $\mathrm{M}^{2+}$ sites. $\mathrm{CO}_{2}$ transient formation rates that are insensitive to $\mathrm{Fe}^{3+}$ methoxy coverages, water titrations over surfaces pre-titrated with $\mathrm{NO}$, and cumulative $\mathrm{CO}_{2}$ yields per $\mathrm{M}^{3+}$ site that remain invariant as a function of activation temperature all point to the involvement of $\mathrm{M}^{3+}$ sites in deep oxidation. Methoxy intermediates play a key role in both methanol and acetaldehyde formation, with acetaldehyde formation in the absence of co-fed methanol occurring through secondary reactions of methanol molecules formed as a result of primary methoxy-water reactions. Acetaldehyde formation does not occur when purely methanol is fed over a methoxy-covered surface, suggesting that the presence of water is necessary for producing acetaldehyde, not ethanol, as the $\mathrm{C} 2$ oxygenate. Relative rates of propagation of water and methanol concentration fronts determine the ratio of cumulative methoxy-water and methoxymethanol encounters, and hence acetaldehyde selectivity; we show that these encounters can be 'forced' in either direction by varying inlet water partial pressures and/or flow rates. Although tri-chromium and tri-iron nodes both enable $\mathrm{C}-\mathrm{C}$ bond formation steps, tri-chromium ones do so at significantly lower water extraction pressures, evidencing the potential for tuning $\mathrm{C} 2$ oxygenate selectivity merely by varying the identity of the metal atom constituting the oxo-bridged trimer. Elucidation of the role of metal identity and oxidation state in $\mathrm{C}-\mathrm{H}$ bond scission and $\mathrm{C}-\mathrm{C}$ bond formation steps is enabled, first and foremost, by the high level of definition, uniformity, and thermal stability of MIL-100 nodes. We assert, in this vein, that the study and use of MOF materials toward catalytic applications more generally could play a meaningful role in overcoming persistent limitations in the development of structure-property relationships that result at least in part directly from intractable levels of heterogeneity in (in)active site speciation.

\section{References}

1. Tang P, Zhu Q, Wu Z, Ma D. Methane activation: the past and future.Energy Environ Sci . 2014;7:25802591.

2. York APE, Xiao T, Green MLH. Brief overview of the partial oxidation of methane to synthesis gas. Top 
Catal . 2003;22(3-4):345-358.

3. West NM, Miller AJM, Labinger JA, Bercaw JE. Homogeneous syngas conversion. Coord Chem Rev . 2011;255(7-8):881-898.

4. Gunay A, Theopold KH. C-H bond activations by metal oxo compounds. Chem Rev . 2010;110(2):10601081.

5. Sharpless KB, Flood TC. Oxotransition Metal Oxidants as Mimics for the Action of Mixed-Function Oxygenases. "NIH Shift" with Chromyl Reagents. J Am Chem Soc . 1971;93(9):2316-2318.

6. Ortiz De Montellano PR. Hydrocarbon hydroxylation by cytochrome P450 enzymes. Chem Rev . 2010;110(2):932-948.

7. Mahyuddin MH, Shiota Y, Yoshizawa K. Methane selective oxidation to methanol by metal-exchanged zeolites: A review of active sites and their reactivity. Catal Sci Technol . 2019;9(8):1744-1768.

8. Crabtree RH. Alkane C-H activation and functionalization with homogeneous transition metal catalysts: A century of progress - A new millennium in prospect. J Chem Soc Dalt Trans . 2001;(17):2437-2450.

9. Dong Y, Fujii H, Hendrich MP, Leising RA, Pan G, Randall CR, Wilkinson EC, Zang Y, Que L, Fox BG, Kauffmann K, Münck E. A High-Valent Nonheme Iron Intermediate. Structure and Properties of $\left[\mathrm{Fe}_{2}(\mu-\right.$ $\left.\mathrm{O})_{2}(5-\mathrm{Me}-\mathrm{TPA})_{2}\right]\left(\mathrm{ClO}_{4}\right)_{3}$. J Am Chem Soc . 1995;117(10):2778-2792.

10. Sturgeon BE, Burdi D, Chen S, Huynh BH, Edmondson DE, Stubbe JA, Hoffman BM. Reconsideration of $\mathrm{X}$, the diiron intermediate formed during cofactor assembly in E. coli ribonucleotide reductase. $J \mathrm{Am}$ Chem Soc . 1996;118(32):7551-7557.

11. Lee S-K, Nesheim JC, Lipscomb JD. Transient Intermediates of the Methane Monooxygenase Catalytic Cycle. J Biol Chem . 1993;268(29):21569-21577.

12. Liu KE, Salifoglou A, Wang D, Huynh BH, Edmondson DE, Lippard SJ. Spectroscopic Detection of Intermediates in the Reaction of Dioxygen with the Reduced Methane Monooxygenase Hydroxylase from Methylococcus capsulatus (Bath). J Am Chem Soc . 1994;116(16):7465-7466.

13. Hausinger RP. Fe(II)/ $\alpha$-ketoglutarate-dependent hydroxylases and related enzymes. Crit Rev Biochem Mol Biol . 2004;39(1):21-68.

14. Martinez S, Hausinger RP. Catalytic mechanisms of Fe(II)- and 2-Oxoglutarate-dependent oxygenases. J Biol Chem . 2015;290(34):20702-20711.

15. Snyder BER, Vanelderen P, Bols ML, Hallaert SD, Böttger LH, Ungur L, Pierloot K, Schoonheydt RA, Sels BF, Solomon EI. The active site of low-temperature methane hydroxylation in iron-containing zeolites.Nature . 2016;536(7616):317-321.

16. Sobolev VI, Dubkov KA, Panna O V., Panov GI. Selective oxidation of methane to methanol on a FeZSM-5 surface. Stud Surf Sci Catal . 1994;81(C):387-392.

17. Knops-Gerrits PP, Goddard WA. Methane partial oxidation in iron zeolites: Theory versus experiment. J Mol Catal A Chem . 2001;166(1):135-145.

18. Hammond C, Forde MM, Ab Rahim MH, Thetford A, He Q, Jenkins RL, Dimitratos N, Lopez-Sanchez JA, Dummer NF, Murphy DM, Carley AF, Taylor SH, Willock DJ, Stangland EE, Kang J, Hagen H, Kiely CJ, Hutchings GJ. Direct catalytic conversion of methane to methanol in an aqueous medium by using copper-promoted Fe-ZSM-5. Angew Chemie - Int Ed . 2012;51(21):5129-5133.

19. Göltl F, Michel C, Andrikopoulos PC, Love AM, Hafner J, Hermans I, Sautet P. Computationally Exploring Confinement Effects in the Methane-to-Methanol Conversion over Iron-Oxo Centers in Zeolites. ACS Catal . 2016;6(12):8404-8409. 
20. Reynolds RA, Dunham WR, Coucouvanis D. Kinetic Lability, Structural Diversity, and Oxidation Reactions of New Oligomeric, Anionic Carboxylate-Pyridine Complexes. Inorg Chem . 2002;37(6):1232-1241.

21. Stassinopoulos A, Caradonna JP. A Binuclear Non-Heme Iron Oxo-Transfer Analog Reaction System: Observations and Biological Implications. J Am Chem Soc . 1990;112(19):7071-7073.

22. Xue G, Wang D, De Hont R, Fiedler AT, Shan X, Munck E, Que L. A synthetic precedent for the $\left[\mathrm{FeIV}_{2}(\mathrm{O})_{2}\right]$ diamond core proposed for methane monooxygenase intermediate Q. Proc Natl Acad Sci . 2007;104(52):20713-20718.

23. Mukerjee S, Stassinopoulus A, Caradonna JP. Iodosylbenzene oxidation of alkanes, alkenes, and sulfides catalyzed by binuclear non-heme iron systems: Comparison of non-heme iron versus heme iron oxidation pathways. J Am Chem Soc . 1997;119(34):8097-8098.

24. Do LH, Lippard SJ. Evolution of strategies to prepare synthetic mimics of carboxylate-bridged diiron protein active sites. J Inorg Biochem . 2011;105(12):1774-1785.

25. Watton SP, Fuhrmann P, Pence LE, Caneschi A, Cornia A, Abbati GL, Lippard SJ. A Cyclic Octadecairon(III) Complex, the Molecular 18-Wheeler. Angew Chemie (International Ed English) . 1997;36(24):27742776 .

26. Vincent JB, Huffman JC, Christou G, Li Q, Nanny MA, Hendrickson DN, Fong RH, Fish RH. Modeling the Dinuclear Sites of Iron Biomolecules: Synthesis and Properties of $\mathrm{Fe}_{2} \mathrm{O}(\mathrm{OAc})_{2} \mathrm{Cl}_{2}$ (bipy $)_{2}$ and Its Use as an Alkane Activation Catalyst. J Am Chem Soc . 1988;110(20):6898-6900.

27. Armstrong WH, Roth ME, Lippard SJ. Tetranuclear Iron-Oxo Complexes. Synthesis, Structure, and Properties of Species Containing The Nonplanar $\left\{\mathrm{Fe}_{4} \mathrm{O}_{2}\right\}^{8+}$ Core and Seven Bridging Carboxvlate Ligands. J Am Chem Soc . 1987;109(21):6318-6326.

28. Terminal L, Dicarboxylate B. A general method for Assembling ( $\mu$ Oxo)bis( $\mu$ carboxylato)diiron(III) Complexes with Labile Terminal Sites Using a Bridging Dicarboxylate Ligand. Inorg Chem . 1989;28(26):45574558 .

29. Zecchina A, Rivallan M, Berlier G, Lamberti C, Ricchiardi G. Structure and nuclearity of active sites in Fe-zeolites: Comparison with iron sites in enzymes and homogeneous catalysts. Phys Chem Chem Phys . 2007;9(27):3483-3499.

30. Pirngruber GD, Roy PK, Weiher N. An in situ X-ray absorption spectroscopy study of $\mathrm{N}_{2} \mathrm{O}$ decomposition over Fe-ZSM-5 prepared by chemical vapor deposition of $\mathrm{FeCl}_{3}$. J Phys Chem B . 2004;108(36):1374613754 .

31. Nechita MT, Berlier G, Ricchiardi G, Bordiga S, Zecchina A. New precursor for the post-synthesis preparation of Fe-ZSM-5 zeolites with low iron content. Catal Letters . 2005;103(1-2):33-41.

32. Baek J, Rungtaweevoranit B, Pei X, Park M, Fakra SC, Liu Y-S, Matheu R, Alshmimri SA, Alshehri S, Trickett CA, Somorjai GA, Yaghi OM. Bioinspired Metal-Organic Framework Catalysts for Selective Methane Oxidation to Methanol. J Am Chem Soc . 2018;140:18208-18216.

33. Zheng J, Ye J, Ortuño MA, Fulton JL, Gutiérrez OY, Camaioni DM, Motkuri RK, Li Z, Webber TE, Mehdi BL, Browning ND, Penn RL, Farha OK, Hupp JT, Truhlar DG, Cramer CJ, Lercher JA. Selective Methane Oxidation to Methanol on Cu-Oxo Dimers Stabilized by Zirconia Nodes of an NU-1000 MetalOrganic Framework. J Am Chem Soc . 2019;141(23):9292-9304.

34. Osadchii DY, Olivos-Suarez AI, Szécsényi Á, Li G, Nasalevich MA, Dugulan IA, Crespo PS, Hensen EJM, Veber SL, Fedin M V., Sankar G, Pidko EA, Gascon J. Isolated Fe sites in metal organic frameworks catalyze the direct conversion of methane to methanol. ACS Catal . 2018;8(6):5542-5548.

35. Hall JN, Bollini P. Low-Temperature, Ambient Pressure Oxidation of Methane to Methanol Over Every Tri-Iron Node in a Metal-Organic Framework Material. Chem - A Eur J . 2020;26(70):16639-16643. 
36. Xiao DJ, Bloch ED, Mason JA, Queen WL, Hudson MR, Planas N, Borycz J, Dzubak AL, Verma P, Lee K, Bonino F, Crocella V, Yano J, Bordiga S, Truhlar DG, Gagliardi L, Brown CM, Long JR. Oxidation of ethane to ethanol by $\mathrm{N}_{2} \mathrm{O}$ in a metal-organic framework with coordinatively unsaturated iron(II) sites. Nat Chem . 2014;6(7):590-595.

37. Verma P, Vogiatzis KD, Planas N, Borycz J, Xiao DJ, Long JR, Gagliardi L, Truhlar DG. Mechanism of oxidation of ethane to ethanol at Iron(IV)-oxo sites in magnesium-diluted $\mathrm{Fe}_{2}$ (dobdc).J Am Chem Soc . 2015; 137(17):5770-5781.

38. Hirao H, Ng WKH, Moeljadi AMP, Bureekaew S. Multiscale model for a metal-organic framework: High-spin rebound mechanism in the reaction of the oxoiron(IV) species of Fe-MOF-74. ACS Catal . 2015;5(6):3287-3291.

39. Simons MC, Vitillo JG, Babucci M, Hoffman AS, Boubnov A, Beauvais ML, Chen Z, Cramer CJ, Chapman KW, Bare SR, Gates BC, Lu CC, Gagliardi L, Bhan A. Structure, Dynamics, and Reactivity for Light Alkane Oxidation of Fe(II) Sites Situated in the Nodes of a Metal-Organic Framework. J Am Chem Soc . 2019;141(45):18142-18151.

40. Vitillo JG, Bhan A, Cramer CJ, Lu CC, Gagliardi L. Quantum Chemical Characterization of Structural Single Fe(II) Sites in MIL-Type Metal-Organic Frameworks for the Oxidation of Methane to Methanol and Ethane to Ethanol. ACS Catal . 2019;9:2870-2879.

41. Barona M, Snurr RQ. Exploring the Tunability of Trimetallic MOF Nodes for Partial Oxidation of Methane to Methanol. ACS Appl Mater Interfaces . 2020;12(25):28217-28231.

42. Ferey G, Serre C, Mellot-Draznieks C, Millange F, Surble S, Dutour J, Margiolaki I. A hybrid solid with giant pores prepared by a combination of targeted chemistry, simulation, and powder diffraction. Angew Chem Int Ed . 2004;43(46):6296-6301.

43. Yoon JW, Seo Y-K, Hwang YK, Chang J-S, Leclerc H, Wuttke S, Bazin P, Vimont A, Daturi M, Bloch E, Llewellyn PL, Serre C, Horcajada P, Greneche J-M, Rodrigues AE, Ferey G. Controlled Reducibility of a Metal-Organic Framework with Coordinatively Unsaturated Sites for Preferential Gas Sorption. Angew Chem Int Ed . 2010;49(34):5949-5952.

44. Leclerc H, Vimont A, Lavalley JC, Daturi M, Wiersum AD, Llwellyn PL, Horcajada P, Ferey G, Serre C. Infrared study of the influence of reducible iron(III) metal sites on the adsorption of $\mathrm{CO}, \mathrm{CO}_{2}$, propane, propene and propyne in the mesoporous metalorganic framework MIL-100. Phys Chem Chem Phys . 2011;13(24):11748-11756.

45. Hall JN, Bollini P. Enabling Access to Reduced Open-Metal Sites in Metal-Organic Framework Materials through Choice of Anion Identity: The Case of MIL-100(Cr). ACS Mater Lett . 2020;2:838-844.

46. Yuranov I, Bulushev DA, Renken A, Kiwi-Minsker L. Benzene hydroxylation over FeZSM-5 catalysts: Which Fe sites are active? J Catal . 2004;227(1):138-147.

47. Pirngruber GD, Roy PK, Weiher N. An in Situ X-ray Absorption Spectroscopy Study of $\mathrm{N}_{2} \mathrm{O}$ Decomposition over Fe-ZSM-5 Prepared by Chemical Vapor Deposition of $\mathrm{FeCl}_{3}$. J Phys Chem B . 2004;108:1374613754 .

48. Wood BR, Reimer JA, Bell AT, Janicke MT, Ott KC. Methanol formation on Fe/Al-MFI via the oxidation of methane by nitrous oxide. J Catal . 2004;225:300-306.

49. Rana BS, Singh B, Kumar R, Verma D, Bhunia MK, Bhaumik A, Sinha AK. Hierarchical mesoporous Fe/ZSM-5 with tunable porosity for selective hydroxylation of benzene to phenol. J Mater Chem . 2010;20:8575-8581.

50. Zhang F, Shi J, Jin Y, Fu Y, Zhong Y, Zhu W. Facile synthesis of MIL-100(Fe) under HF-free conditions and its application in the acetalization of aldehydes with diols. Chem Eng J . 2015;259:183-190. 
51. Mao Y, Qi H, Ye G, Han L, Zhou W, Xu W, Sun Y. Green and time-saving synthesis of MIL-100(Cr) and its catalytic performance.Microporous Mesoporous Mater . 2019;274:70-75.

52. Hall JN, Bollini P. Quantification of Open-Metal Sites in Metal-Organic Frameworks Using Irreversible Water Adsorption.Langmuir . 2020;36(5):1345-1356.

53. Rosen AS, Notestein JM, Snurr RQ. Structure-Activity Relationships That Identify Metal-Organic Framework Catalysts for Methane Activation.ACS Catal . 2019;9(4):3576-3587.

54. Barona M, Snurr RQ. Exploring the Tunability of Trimetallic MOF Nodes for Partial Oxidation of Methane to Methanol. ACS Appl Mater Interfaces . 2020;12(25):28217-28231.

55. Cho K Bin, Wu X, Lee YM, Kwon YH, Shaik S, Nam W. Evidence for an alternative to the oxygen rebound mechanism in $\mathrm{C}-\mathrm{H}$ bond activation by non-heme FeIVO complexes. J Am Chem Soc . 2012;134(50):20222-20225.

56. Cho K Bin, Hirao H, Shaik S, Nam W. To rebound or dissociate? This is the mechanistic question in C-H hydroxylation by heme and nonheme metal-oxo complexes. Chem Soc Rev . 2016;45(5):1197-1210.

57. Starokon E V., Parfenov M V., Arzumanov SS, Pirutko L V., Stepanov AG, Panov GI. Oxidation of methane to methanol on the surface of FeZSM-5 zeolite. J Catal . 2013;300:47-54.

58. Starokon E V., Parfenov M V., Pirutko L V., Abornev SI, Panov GI. Room-temperature oxidation of methane by $\alpha$-oxygen and extraction of products from the FeZSM-5 surface. $J$ Phys Chem $C$. 2011;115(5):2155-2161. 